\title{
Comparison of Talitrus saltator (Amphipoda, Talitridae) biology, dynamics, and secondary production in Atlantic (Portugal) and Mediterranean (Italy and Tunisia) populations
}

\author{
J.C. Marques ${ }^{\mathrm{a}, *}$, S.C. Gonçalves ${ }^{\mathrm{a}}$, M.A. Pardal ${ }^{\mathrm{a}}$, L. Chelazzi ${ }^{\mathrm{b}}$, I. Colombinic, \\ M. Fallaci ${ }^{c}$, M.F. Bouslama ${ }^{\mathrm{d}}$, M. El Gtari ${ }^{\text {d }}$, F. Charfi-Cheikhrouha ${ }^{\mathrm{d}}$, F. Scapini ${ }^{\mathrm{c}}$ \\ ${ }^{\mathrm{a}} I M A R$ - Institute of Marine Research, Department of Zoology, Faculty of Sciences and Technology, \\ University of Coimbra, 3004-517 Coimbra, Portugal \\ ${ }^{\mathrm{b}}$ Istituto per lo studio degli Ecosistemi del CNR, Via Romana 17, 50125 Florence, Italy

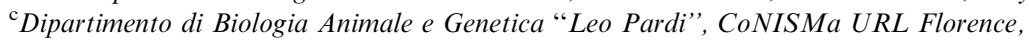 \\ Via Romana 17, 50125 Florence, Italy \\ ${ }^{\mathrm{d}}$ Laboratoire de Bio-Ecologie et Systématique Evolutive, Departement de Biologie, Faculté des Sciences de \\ Tunis, Campus Universitaire, 2092 Manar II, Tunis, Tunisia
}

Received 23 October 2001; accepted 31 July 2002

\begin{abstract}
Talitrus saltator biology, population dynamics, and reproduction were studied more or less simultaneously at three sand beaches: Lavos, on the western coast of Portugal; Collelungo, on the Italian coast of the Thyrrenian Sea; and Zouara, on the northern coast of Tunisia. The species exhibited a consistent pattern of aggregated distribution. Densities were higher at Lavos than at Collelungo and Zouara. Reproduction took place from early March to late September at Lavos and Collelungo, and from late February to early November at Zouara. The average sex ratio was favourable to males at Lavos and Collelungo, and to females at Zouara. Based on data from Lavos, the population abundance was positively correlated with temperature, while the percentage of juveniles in the population was positively correlated with temperature and sediment moisture. Adult individuals from the Atlantic population were larger than the Mediterranean ones, while newborn individuals from the Mediterranean were slightly larger than Atlantic ones. Life span was estimated at 7-11 months at Lavos, 6-9 months at Collelungo, and 6-8 months at Zouara. Cohorts born at the beginning of the reproductive period tend to have shorter lives than the ones born later in the season, with longer life spans occurring in cohorts that crossed the winter to breed in the next year. The minimum period necessary for sexual differentiation after birth was estimated at \pm 4 weeks at Lavos, \pm 3 weeks at Collelungo, and \pm 4.5 weeks at Zouara, for males, and \pm 6 weeks at Lavos, and \pm 5 weeks at Collelungo and Zouara, for females. The period necessary for female's sexual maturation after being born was estimated at \pm 10 weeks at Lavos, and \pm 8 weeks at Collelungo and Zouara. At the studied sites, $T$. saltator appeared as semiannual species, with iteroparous females appearing to produce at least two broods per year, and exhibited a bivoltine life cycle. Growth production $(P)$ was estimated at $0.74 \mathrm{~g} \mathrm{~m}^{-2} \mathrm{yr}^{-1}$ ashfree dry weight (AFDW; $17.7 \mathrm{~kJ} \mathrm{~m}^{-2} \mathrm{yr}^{-1}$ ) at Lavos, $0.12 \mathrm{~g} \mathrm{~m}^{-2} \mathrm{yr}^{-1}$ AFDW $\left(2.8 \mathrm{~kJ} \mathrm{~m}^{-2} \mathrm{yr}^{-1}\right.$ ) at Collelungo, and $0.61 \mathrm{~g} \mathrm{~m}^{-2} \mathrm{yr}^{-1}$ $\operatorname{AFDW}\left(14.3 \mathrm{~kJ} \mathrm{~m}^{-2} \mathrm{yr}^{-1}\right)$ at Zouara. Elimination production $(E)$ was estimated at $1.40 \mathrm{~g} \mathrm{~m}^{-2} \mathrm{yr}^{-1} \mathrm{AFDW}\left(33.5 \mathrm{~kJ} \mathrm{~m}^{-2} \mathrm{yr}^{-1}\right)$ at Lavos, $0.20 \mathrm{~g} \mathrm{~m}^{-2} \mathrm{yr}^{-1}$ AFDW $\left(4.8 \mathrm{~kJ} \mathrm{~m}^{-2} \mathrm{yr}^{-1}\right)$ at Collelungo, and $1.11 \mathrm{~g} \mathrm{~m}^{-2} \mathrm{yr}^{-1}$ AFDW $\left(26.6 \mathrm{~kJ} \mathrm{~m}^{-2} \mathrm{yr}^{-1}\right)$ at Zouara. The average annual biomass $(\bar{B})$ (standing stock) was estimated at $0.13 \mathrm{~g} \mathrm{~m}^{-2}$ at Lavos, $0.014 \mathrm{~g} \mathrm{~m}^{-2}$ at Collelungo, and $0.084 \mathrm{~g} \mathrm{~m}^{-2}$ at Zouara, resulting in $P / \bar{B}$ ratios of 5.7 at Lavos, 8.2 at Collelungo, and 7.3 at Zouara, and $E / \bar{B}$ ratios of 10.8 at Lavos, 14.4 at Collelungo, and 13.1 at Zouara. The present results, combined with information from literature, revealed a geographic variation in $T$. saltator populations with regard to their morphological characteristics, growth rates, life spans, and life cycles.
\end{abstract}

(c) 2003 Elsevier Ltd. All rights reserved.

Keywords: Talitrus saltator; biology; population dynamics; Atlantic; Mediterranean; geographical variation

\footnotetext{
* Corresponding author.

E-mail address: jcmimar@ci.uc.pt (J.C. Marques).
} 


\section{Introduction}

The littoral zone of sandy beaches constitutes a harsh environment, and the animal communities living at the interface between land and sea have evolved ecophysiologically (e.g. Morrit \& Spicer, 1982) and behaviourally to cope with the environmental constraints of this changing habitat. However, in recent times, human impact has severely threatened the sand littoral ecosystems, stressing the need to investigate the extent to which organisms can adapt to environmental and human-induced changes, foreseeing a sustainable use of beach environments. In fact, biological responses to environmental changes are complex, since different phenotypes may result from modification of gene expression, and the genome may also change through natural selection (Hoffmann \& Parsons, 1991). It is, therefore, important to evaluate the adaptation of local populations to such changes, and the degree of natural variation between and within populations appears as a useful indicator (Hazlett, 1988).

Talitrid amphipods constitute one of the predominant arthropod groups in sandy beach fauna, exhibiting a dynamic equilibrium with environment. Owing to their ecological importance, talitrids have been studied worldwide from different points of view. For example, a large number of articles have been published on talitrid behaviour, behavioural plasticity, and genetic determination of different behaviours (e.g. Gerard, Vancassel, \& Laffort, 1993; Scapini, 1997; Scapini, Lagar, \& Mezzeti, 1993), while factors influencing their spatial distribution and oriented movements in sandy beaches have also been studied to a great extent (e.g. Borgioli et al., 1999; Scapini, Buiatti, De Matthaeis, \& Mattoccia, 1995; Scapini, Buiatti, \& Fallaci, 1989; Scapini \& Fasinella, 1990; Scapini, Porri, Borgioli, \& Martelli, 1999; Scapini \& Quochi, 1992). With regard to biodiversity, along the European coasts, talitrid populations have been compared genetically to assess interand intra-specific variations (De Matthaeis, Cobolli, Mattocia, \& Scapini, 1995). Finally, in terms of applied research, a number of articles have been published on trace metals $(\mathrm{Cu}, \mathrm{Zn}, \mathrm{Fe}, \mathrm{Cd}, \mathrm{Pb}, \mathrm{Mn}$, and $\mathrm{Ni})$ concentrations and bioaccumulation by talitrids, and on their role in biomonitoring (e.g. Fialkowski, Rainbow, Fialkowski, \& Smith, 2000; Rainbow, Moore, \& Watson, 1989; Weeks, 1992).

Population size, reproductive strategies, and potential for dispersal between habitats are usually considered to reflect evolutionary fitness. Likewise, it may be assumed that different beaches offer different food resources, and that local populations would vary with regard to feeding habits (see, for example, Pennings, Carefoot, Zimmer, Danko, \& Ziegler, 2000), efficiency in using the available energy, productivity, and reproductive capacity. Nevertheless, there are no comprehensive studies of strand- line talitrids in this respect, and the contribution of this group to the energy of beach ecosystems is still poorly understood. In fact, there are few studies on the reproductive biology and population dynamics of talitrids (Hartog, 1963; Jones \& Wigham, 1993; Marsden, 1991a; Palluault, 1954; Persson, 1999; Van Senus, 1988; Williams, 1978; Williamson, 1951a), and even less on secondary production (e.g. Cardoso \& Veloso, 1996; Van Senus \& McLachlan, 1986).

Talitrids comprise species such as the sandhopper Talitrus saltator, widely distributed along the Mediterranean and European sandy coasts, and generally abundant where it occurs. Williams (1978) provided an elegant approach to studies on the annual pattern of reproduction of this species in northern Europe (British Isles). The underlying objective of the present study was to investigate the adaptation of $T$. saltator to life in sandy beaches, and simultaneously to provide data necessary for the development of a population dynamics model (Anastácio, Gonçalves, Pardal, \& Marques, 2003). For this purpose, a comparative study of Atlantic and Mediterranean populations was carried out, focusing on their biology, population dynamics, and productivity.

\section{Materials and methods}

\subsection{Study sites}

To allow comparisons between Atlantic and Mediterranean populations, three different sets of data were provided by sampling campaigns carried out at three sandy beaches: Lavos, on the western coast of Portugal; Collelungo, on the Italian coast of the Thyrrenian Sea; and Zouara, on the northern coast of Tunisia (Fig. 1).

The Lavos sandy beach, located on the central region of Portugal, is approximately $25 \mathrm{~km}$ long, between the mouth of the Mondego River and the Ervedeira coastal lagoon, close to Pedrógão, a small village. It is a relatively undisturbed beach, which receives a moderate number of summer visitors. The site chosen for the study, called Cabedelo $\left(40^{\circ} 07^{\prime} 32^{\prime \prime} \mathrm{N}, 8^{\circ} 51^{\prime} 49^{\prime \prime} \mathrm{W}\right)$, located at about $1 \mathrm{~km}$ south from the Mondego river mouth, is a very exposed beach (exposure rate $=15$ ). The eulittoral zone was about $60 \mathrm{~m}$ in width, with an average slope of $2 \%$. Tidal range varies approximately between 2 and $3.5 \mathrm{~m}$, and, consequently, the extension of the intertidal area ranges from approximately $30 \mathrm{~m}$ in width, on neap tides, to $45 \mathrm{~m}$, on spring tides. During storms, the beach may be almost completely inundated, which causes the deposition of large masses of drift wrack, mainly macroalgae, from rocky shores located to the north. The sediment was classified as medium sand, with a mean grain size between 0.250 and $0.500 \mathrm{~mm}$ (Wentworth scale) (Brown \& McLachlan, 1990). 


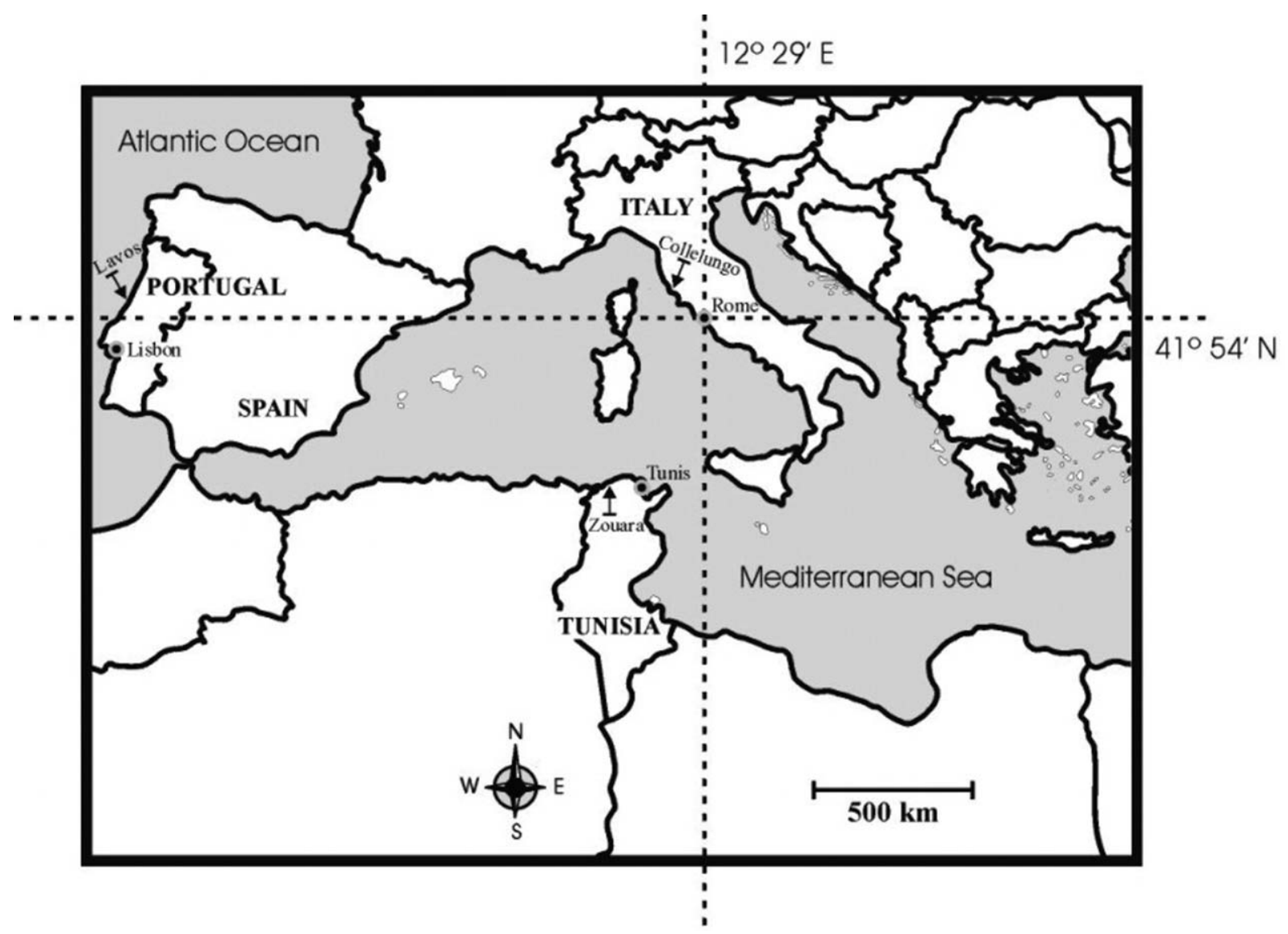

Fig. 1. Study sites: Lavos (Atlantic, western coast of Portugal), Collelungo (Thyrrenian Sea, Italy), and Zouara (northern coast of Tunisia).

No vegetation was found in the supralittoral area. The foredune was approximately $2.5-3 \mathrm{~m}$ in height, presenting a vegetation cover dominated by a single species, Ammophila arenaria, while in the secondary dune, we also found Euphorbia paralias and Cakile maritima as species of major importance.

The Collelungo sandy beach, located in the southern part of Tuscany, is about $7 \mathrm{~km}$ long, between the Ombrone River and the beginning of the rocky shores, east-southeast of the Uccellina mountains. It constitutes a well-preserved sandy beach ecosystem, belonging to the Regional Park of Maremma. However, in the past 25 years, the coastline profile has been modified a great deal in relation to the decrease of sediment transportation of the Ombrone River. This has caused beach erosion at the mouth of the river and accretion at Collelungo $\left(42^{\circ} 37^{\prime} 55^{\prime \prime} \mathrm{N}, 11^{\circ} 04^{\prime} 57^{\prime \prime} \mathrm{E}\right)$, the site where the study was carried out.

Collelungo is an exposed beach (exposure rate $=12$ ), presenting a wide eulittoral (average width about $40 \mathrm{~m}$ ) with no vegetation. In relation to its slight slope $(1 \%)$, this area was subjected to heavy inundation during sea storms that caused stranding of an abundant quantity of the phanerogama plant Cymodocea nodosa and of driftwood. The sediment mean grain size ranged between 0.250 and $0.500 \mathrm{~mm}$, corresponding also to medium sand (Wentworth scale). Mean tidal excursions were from 20 to $30 \mathrm{~cm}$ at neap and spring tides, respectively. The supralittoral was characterised by typical pioneer plants, such as Ammophila arenaria, Cakile maritime, and Euphorbia paralias. The dune was $3 \mathrm{~m}$ in height and presented a vegetation cover mainly composed of $A$. arenaria and E. paralias. Retrodunal areas were characterised by Mediterranean maquis and pine wood vegetation planted a few centuries ago.

The Zouara beach-dune system, located in the northern coast of Tunisia, extends for about $25 \mathrm{~km}$, between Tabarka and Cap Negro. The system is interrupted at several points by the mouths of several oueds, El Kebir, Bouterfess, Berkoukech, and Zouara (the most important one). The catchments are formed by Oued Zouara discharges into the sea at Zouara beach-a well-developed beach backed up by high coastal dunes. In the last 2 years, this beach-dune system has undergone severe human impact due to the construction of a dam across the Oued, which seriously affected the equilibrium of the local coastal line. The dune vegetation from Tabarka to Cap Negro includes 
many species typical of this harsh environment, even though some (e.g. Cakile maritima) were rare. The dominant species in the dune were Ammophila arenaria, Eryngium maritimum, and Euphorbia paralias, while the annual dominant species were Cutandia divaricata, Silene succulenta, and Polygonum maritimum.

The site chosen for the study $\left(37^{\circ} 0^{\prime} 41^{\prime \prime} \mathrm{N}, 08^{\circ} 53^{\prime} 26^{\prime \prime} \mathrm{E}\right)$ was located at $3 \mathrm{~km}$ west from the mouth of Oued (River) Zouara, constituting a very exposed beach (exposure rate $=16$ ). The eulittoral zone was about $50 \mathrm{~m}$ in width, with an average slope of $3 \%$. The first dune belt was about $20 \mathrm{~m}$ in height. Mean tidal excursions ranged from 10 to $20 \mathrm{~cm}$ at neap and spring tides, respectively, and, therefore, tides were frequently hidden by local wave action. Beach debris was limited. The sediment was mainly medium sand, with a mean grain size ranging from 0.250 to $0.500 \mathrm{~mm}$ (Wentworth scale).

All the three sites correspond to relatively undisturbed beaches. Nevertheless, in the case of Zouara, there are development plans for the whole area, which may alter substantially the present scenario in the near future, with a probable increase of human pressure over the beach and the dunes. The preparation of management scenarios appears, therefore, as a priority, and Talitrus saltator as an indicator species to assess the impact of human activities on the beach communities may constitute a useful tool.

\subsection{Sampling programme}

At the three study sites, quantitative samples were taken from the sandy beach communities, which consisted mainly of arthropod populations. The sampling period at Lavos (Atlantic, western coast of Portugal) lasted 16 months, from March 1999 to June 2000, while at Collelungo (western coast of Italy), it lasted from February 1999 to January 2000, and at Zouara (northwestern coast of Tunisia), from December 1998 to December 1999. Owing to logistic constraints, it was not possible for samples to be taken exactly coincidentally, but there was a significant overlap of activities at the three sites. The study period was longer at Lavos in order to obtain a larger data set necessary for further modelling development, but again it was not possible logistically to do this on the other two beaches.

Samples were expressed as a function of the sampled area, always trying to collect at least 100 specimens of Talitrus saltator (Amphipoda), considered as the minimum suitable number for modal analysis of the population structure. Three teams participated in the sampling effort, and the field methodologies were previously inter-calibrated through reciprocal visits to the different sites.

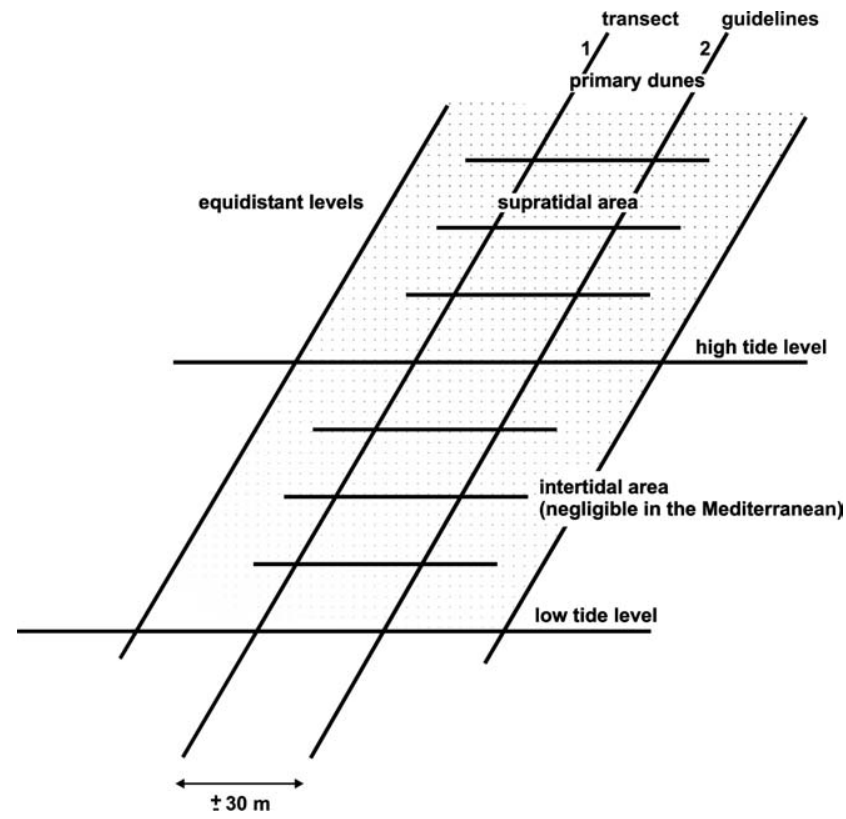

Fig. 2. General scheme of the sampling design, which was adapted to each site. The intertidal area, for instance, is negligible in Mediterranean beaches $( \pm 0.30 \mathrm{~m})$. Samples (one per level) were taken at regular intervals along two transects (spaced approximately $30 \mathrm{~m}$ ), from the shoreline to the base of the dunes.

At each beach, from the sea to land, the intertidal and supratidal areas were distinguished, followed by the primary dunes. Samples were taken at regular intervals along two transects from the shoreline to the base of the dune (Fig. 2). No quantitative samplings were carried out in the dune, because it was considered that it would cause too much physical disturbance. This sampling strategy allowed simultaneously to account for differential vertical distribution and to collect the minimum of individuals necessary for statistical analysis. Sampling occurred every 15 days, during the neap tides, and, whenever possible, rainy days were avoided because precipitation usually causes animal dispersion.

Each replicate was obtained using a metal or woodsquare of $0.25 \mathrm{~m}^{2}$ to restrict the sampling area. Next, using a small scoop, the first $20 \mathrm{~cm}$ of the sand surface layer, where the organisms would most probably be found, was removed. The sand was sieved through $1 \mathrm{~mm}$ mesh size bags, which retained all individuals of Talitrus saltator, including newly hatched juveniles. Animals and the largest sand fraction were retained in the sieve and kept alive in plastic bags, until separated in the laboratory where the animals were preserved in $70 \%$ alcohol.

To investigate the influence of physicochemical factors on the Talitrus saltator population at Lavos only, for each replicate, before sieving the sand, all superficial debris were collected, sieved through a $2 \mathrm{~mm}$ mesh size bag, and preserved in a plastic bag. These 
samples were frozen at $-18^{\circ} \mathrm{C}$ and kept for a period no longer than 2 months before the analysis of organic matter (potential food, $\mathrm{mg} \mathrm{m}^{-2}$ ). The organic matter was determined as ash-free dry weight (AFDW) after combustion at $550^{\circ} \mathrm{C}$ during $12 \mathrm{~h}$. Sediment samples were also taken, kept in plastic bags, and immediately analysed at the laboratory to estimate sediment moisture, which was calculated as the difference between the initial weight of sediment samples and its dry weight after $24 \mathrm{~h}$ at $60^{\circ} \mathrm{C}$.

Meteorological data during the study period were obtained from the closest meteorological station. These included average daily precipitation, visibility, cloudiness, wave height, wave period, and wind velocity, and maximum and minimum daily temperatures.

\subsection{Laboratory procedures}

The goal was to obtain quantitative data on the main biological features, field growth rates, and productivity of the populations of Talitrus saltator at the three study sites, allowing the further calibration of growth models and the development of a population dynamics model.

Field samples were processed at three laboratories in Portugal (Coimbra), Italy (Florence), and Tunisia (Tunis), respectively. At each laboratory, collected individuals were measured for the cephalic length (CL), using binocular microscopes equipped with micrometrical ocular lens, calibrated with objective micrometers. When necessary, total length (TL) was estimated from CL through estimated linear equations

$\mathrm{TL}=-1.74516+10.88863 \mathrm{CL}$ for the Lavos population

$\mathrm{TL}=0.515093+8.82335 \mathrm{CL}$ for the Collelungo population

$\mathrm{TL}=0.186381+9.12423 \mathrm{CL}$ for the Zouara population

After being measured, individuals were sexed (males, females, or juveniles) based on the presence of copulatory appendages in the males, and presence of oostegites, with or without setae, in the females. Females with setae were considered as mature, meaning that they would carry eggs soon, or that they had just been released. In the absence of any secondary sexual dimorphic features, individuals were considered juveniles. Specimens were, therefore, classified as: (a) males, (b) resting females, (c) gravid females, or (d) juveniles. The gravid females group included both females carrying eggs and females bearing setae on the oostegites.
Embryos were removed from the brood pouch of gravid females and counted. The average diameter was determined taking into account the length, width, and depth, and eggs were classified, using a simplified version of Williams (1978), as follows:

Stage A: eggs approximately round in shape, although showing internally different aspects of cell division.

Stage $B$ : eggs oval, embryo comma-shaped and showing the initial segmentation of head and limb rudiments, dorsal organ with maximum size.

Stage C: eggs oval, head and limb rudiments clearly visible, appearance of optic rudiment, regression of dorsal organ.

Stage D: eggs oval, head clearly defined, appearance of pigmented eye, limb development completes.

Stage E: hatched juveniles retained in the brood pouch.

However, due to handling, gravid females dropped an undetermined number of embryos from brood pouches, so that any significant statistical analysis regarding brood mortality was impossible.

It was assumed that the relationships between length and weight of the individuals could vary throughout the year. Thus, for each season (spring, summer, autumn, and winter), 150-200 specimens, randomly sampled, were weighed (AFDW, after combustion at $450{ }^{\circ} \mathrm{C}$ during $3 \mathrm{~h}$ ) with a $10^{-5} \mathrm{mg}$ precision. Smaller juveniles could not be weighed individually, and were pooled in groups consisting of specimens of approximately the same size. Data on CL and weight (AFDW) were then used to determine the following equations:

$$
\mathrm{AFDW}=0.00261025 \mathrm{CL}^{3.79929} \text { for the Lavos population }
$$

$$
\begin{aligned}
\mathrm{AFDW}= & 0.0023215 \mathrm{CL}^{2.87104} \text { for the Collelungo } \\
& \text { population }
\end{aligned}
$$

$$
\mathrm{AFDW}=0.0024378 \mathrm{CL}^{2.85113} \text { for the Zouara population }
$$

\subsection{Data analysis}

The spatial distribution of the studied populations was analysed using the index $I=S^{2} / \bar{X}$, where $S^{2}$ is the variance of densities estimated per replicate, expressed as a function of the sampled area, and $\bar{X}$ is the mean density (Elliot, 1977).

Multiple regression models based on data from Lavos (Atlantic) were developed, correlating density, sex ratio, 
percentage of gravid females, and percentage of juveniles in the population determined at each sampling date with physicochemical environmental factors. The fitted regression models were expressed as

$Y^{\prime}=a+b_{1} X_{1}+b_{2} X_{2}+\cdots+b_{k} X_{k}$

where $Y^{\prime}$ is the value of a given dependent variable (e.g. density) predicted by the equation, and $X_{1}, X_{2}, \ldots, X_{k}$ are independent variables (e.g. salinity). The solutions are the estimate of the regression coefficients $a, b_{1}, b_{2}, \ldots, b_{k}$. The significance of the fitted regressions through analysis of variance $(F)$ was tested, using additionally the $t$-test for the regression coefficients. The models were fitted with data following the Stepwise Forward Analysis method performed by the Statgraphics 4.0 statistical package.

Field growth rates were estimated by tracking recognizable modal distributions in the population using size-frequency of distributions $(0.04 \mathrm{~mm}$ length classes) from successive sample dates, following a methodology previously described (Marques, Martins, Teles-Ferreira, \& Cruz, 1994; Marques \& Nogueira, 1991; Pardal, Marques, Metelo, Lillebø, \& Flindt, 2000). Modal distributions are assumed to result from pulses in recruitment, conventionally referred to as cohorts. Size-frequency analysis was carried out using the probability paper method (Harding, 1949), as performed by Cassie $(1954,1963)$. The reliability of the method was tested employing both the $\chi^{2}$ and $G$ tests $(P \leq 0.05)$. Computations were performed using the ANAMOD software (Nogueira, 1992).

Field growth rates were expressed using the Bertalanffy's (Bertalanffy, 1957) model

$L_{t}=L_{\infty}\left(1-\mathrm{e}^{-k\left(t-t_{0}\right)}\right)$

where $L_{t}$ is the length of the organism at a given moment $t, L_{\infty}$ the maximum possible length of the organism, $t$ the given instant, $t_{0}$ the instant at which the organism would have a length 0 , and $k$ is the intrinsic growth rate.

Production estimates were based upon cohort's recognition, taking into account growth production $(P)$ and elimination production $(E)$. Production was estimated by growth and elimination methods as derived by Allen (1971). Approximate values of $P$ and $E$ for each cohort during a given time interval may be expressed as

$P=\left[\left(N_{t}+N_{t+1}\right) / 2\right]\left(\bar{W}_{t+1}-\bar{W}_{t}\right)$ for $\bar{W}_{t+1}>\bar{W}_{t}$

$E=\left[\left(\bar{W}_{t}+\bar{W}_{t+1}\right) / 2\right]\left(N_{t}-N_{t+1}\right)$ for $N_{t}>N_{t+1}$

where $N$ is the density of the cohort at each sample date, $\bar{W}$ the mean individual biomass at each sampling date, and $t$ and $t+1$ are the consecutive sampling dates.
Total values of $P$ and $E$ for each cohort are expressed as

$P=\sum_{t=0}^{t=n}\left[\left(N_{t}+N_{t+1}\right) / 2\right] \Delta \bar{W}$

$E=\sum_{t=0}^{t=n}\left[\left(\bar{W}_{t}+\bar{W}_{t+1}\right) / 2\right] \Delta N$

Total values of $P$ and $E$ for the population are expressed as

$P=\sum_{n=1}^{N} P_{\mathrm{c} n}$

and

$E=\sum_{n=1}^{N} E_{\mathrm{c} n}$

where $P_{\mathrm{c} n}$ and $E_{\mathrm{c} n}$ are the growth and elimination productions of cohort $n$.

The $P / \bar{B}$ and $E / \bar{B}$ ratios were determined, with $\bar{B}$ (mean population biomass) being expressed as

$\bar{B}=(1 / T) \sum_{n=1}^{N}\left(\bar{B}_{n} t\right)$

where $T$ is the period of study, $N$ the number of successive cohorts in the period $T, \bar{B}_{n}$ the mean biomass of cohort $n$, and $t$ is the duration of cohort $n$.

\section{Results}

\subsection{Spatial distribution and abundance}

Talitrus saltator exhibited a consistent pattern of aggregated distribution at the three study sites, the spatial distribution always being higher than 1 (Elliot, 1977). Despite seasonal variations, densities were consistently higher at Lavos beach in the Atlantic, than at Collelungo and Zouara in the Mediterranean (Fig. 3).

Despite differences in density, the pattern of seasonal variation appears to be very similar at Lavos and Collelungo: the lowest densities in late winter, a rapid increase from early spring to June/July, when the maximum is attained, a slight decrease, followed immediately by a second, although smaller, peak in late August, and a gradual decrease from late summer until the next winter (Fig. 3). The pattern of variation is very different at Zouara. Highest densities in the beach were observed during winter, followed by a clear decrease in numbers of Talitrus saltator, which sometimes almost completely disappear from the beach (Fig. 3). 

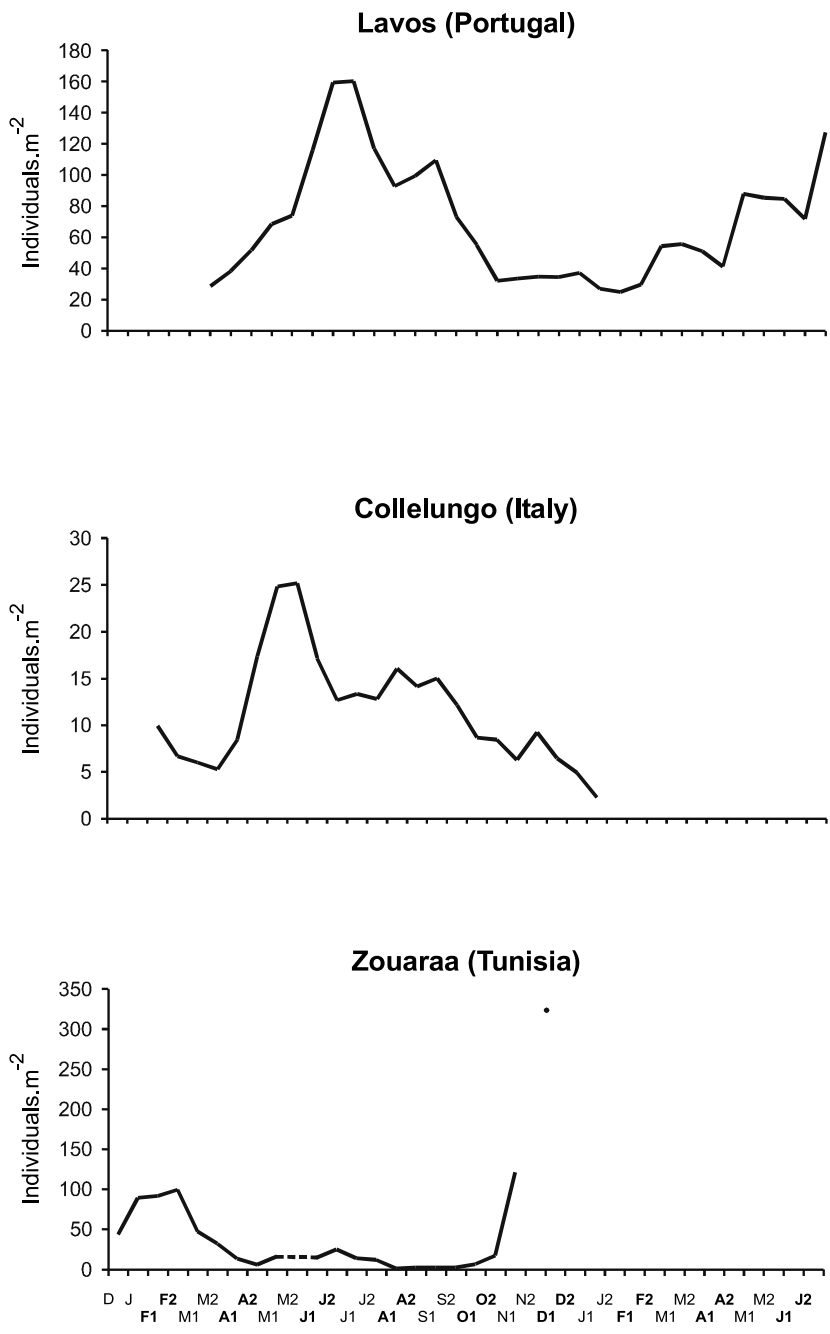

1999

2000

Fig. 3. Variation of Talitrus saltator population density (individuals $\mathrm{m}^{-2}$ ) at the three study sites.

\subsection{Period of reproduction and sex ratio}

The period of reproduction is indicated by the occurrence of gravid females (Fig. 4), consisting of both ovigerous and mature females, and the appearance of new juvenile cohorts in the population (Figs. 4 and 6-8).

The appearance of ovigerous females roughly preceded juvenile recruitment, but there was no synchronization between the females regarding the state of embryonic development, as eggs in all stages occurred at each sampling date. Average diameter of eggs increased $\pm 43 \%$, from stage A to stage $\mathrm{D}$, corresponding to an increase of $\pm 192 \%$ in volume, which is similar to the value of $240 \%$ recorded by Williams (1978).

The period of reproduction was, therefore, very similar in the populations studied on the Atlantic coast of Portugal and in Italy, but clearly longer in North Africa. At Lavos, reproduction took place from early March to late September, with new cohorts being
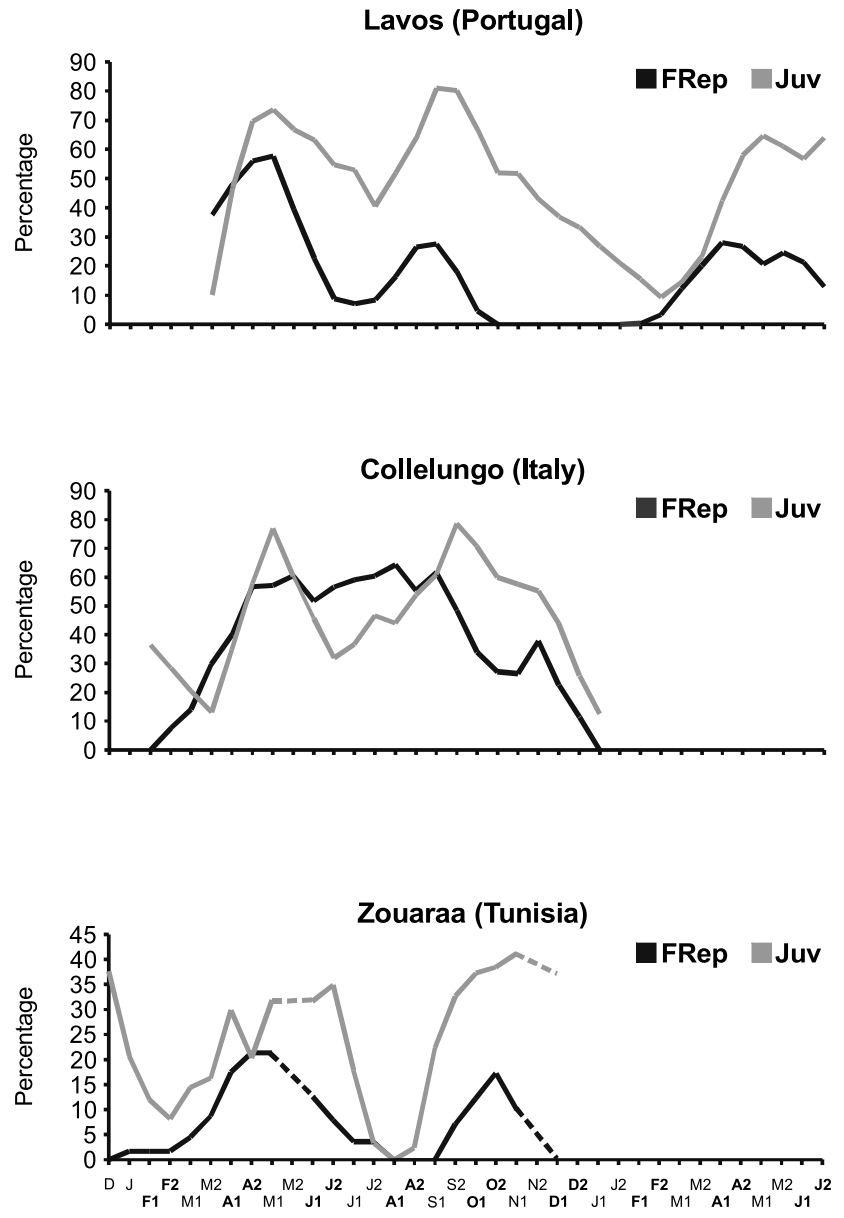

1999

2000

Fig. 4. Percentages of gravid females of Talitrus saltator, relative to the total female population, and of juveniles, relative to the whole population, at the three study sites.

detected in March-July, and one late in early September. The breeding season was similar at Collelungo, from early March to late September, with new cohorts being positively recognized in early April-September. At Zouara, however, breeding occurred from late February to early November, with new cohorts in February, April, June, sometime in the period between July and October, and finally, in November.

Five or six new groups were produced at Lavos, taking into account that cohort 5, consisting of very small animals was detected at the first sampling date. Six were evident at Zouara, while eight new cohorts could be recognized in the Collelungo population. Therefore, despite differences regarding the reproduction period between the North African population and the other two, the reproductive output was more or less equivalent. Additionally, an equivalent pattern was observed at Lavos and Collelungo regarding the variation of the percentage of juveniles in the population (Fig. 4). An initial peak of recruitment occurred in spring, followed by a slacking in early summer, and a new maximum in August and 
September, just before the winter pause. At Zouara, there is a strong suggestion that the same phenomenon might have occurred (Fig. 4), but the available data do not allow the pattern to be recognized clearly.

With regard to the sex ratio, there is a clear difference between Lavos and Collelungo, on one hand, and Zouara, on the other (Fig. 5). At Lavos and Collelungo, the sex ratio was almost always favourable to males (average $1.2: 1$ and $1.04: 1$, respectively), except briefly during spring, at both sites, during the summer (JulyAugust), at Lavos, and in autumn at Collelungo. At Zouara, exactly the contrary was observed, with a dominance of females in the population $(0.54: 1)$, except in early December 1999. This difference will be discussed subsequently.

\subsection{Influence of environmental factors on the population structure}

Data regarding the average values and range of variation of physicochemical factors at Lavos during the whole study period are summarized in Table 1 . The entire data sets regarding the biological variables (density, sex ratio, percentage of gravid females, and percentage of juveniles in the population) and physicochemical factors determined at each sample date were used to establish multiple regression models (stepwise approach).

As might be expected, the population density $(D)$ was positively correlated with temperature $(T)$, as well as the population biomass $(B)$. Moreover, the percentage of juveniles in the population (PJ) was positively correlated with temperature $(T)$ and sediment moisture (SM). The following regression models describe these relations:

$\operatorname{Ln}(1+D)=2.59+0.0987 T \quad\left(r^{2}=0.593 ; P=0.0000\right)$

$B=0.0482+0.0570 T \quad\left(r^{2}=0.19 ; P=0.009\right)$

$\mathrm{PJ}=-57.9+3.72 T+34.1 \mathrm{Ln}(1+\mathrm{SM})$

$\times\left(r^{2}=0.49 ; P=0.000\right.$ for temperature and

$P=0.003$ for sediment moisture).

The positive correlations between density $(D)$ or biomass $(B)$ and temperature $(T)$ may be interpreted as
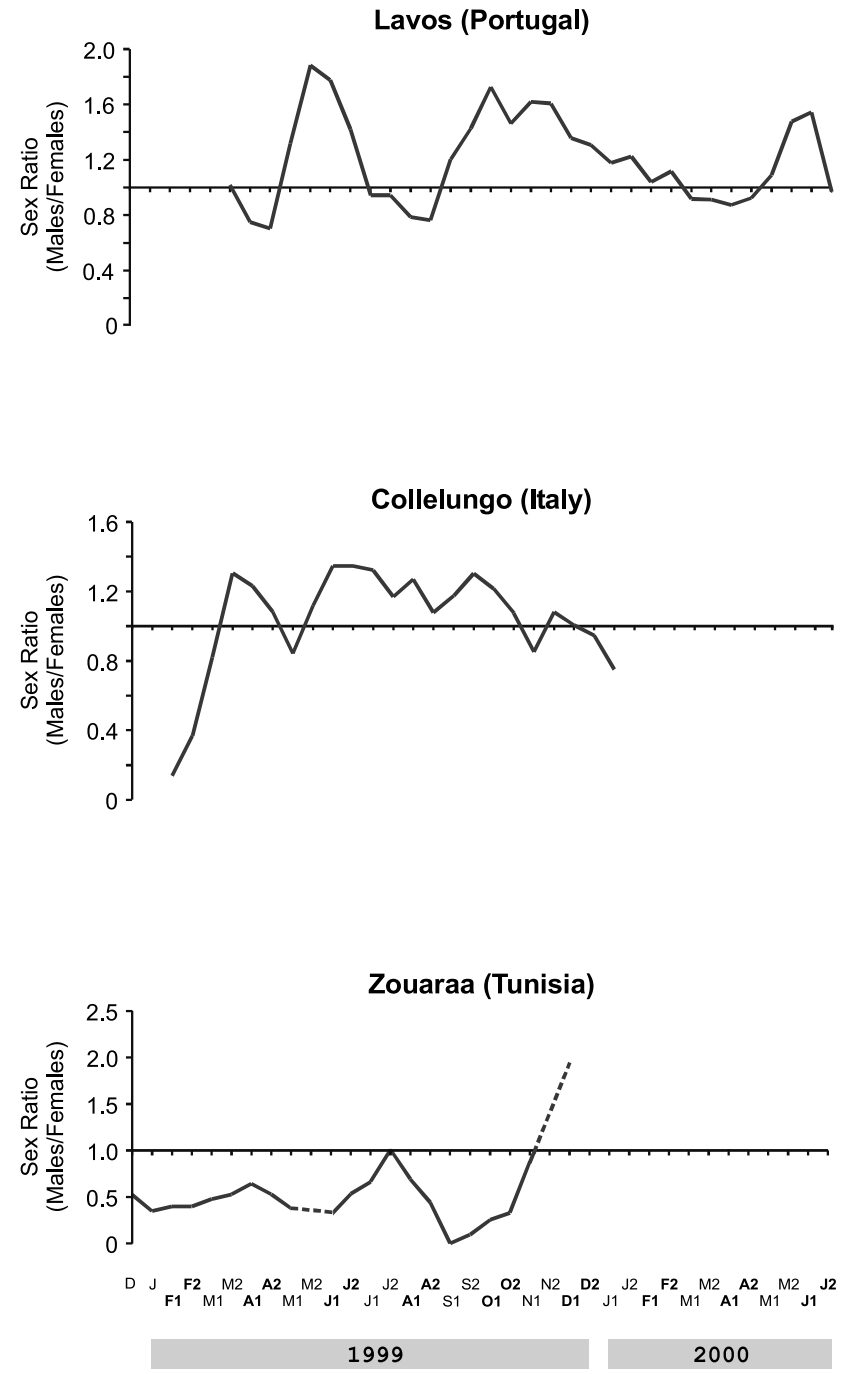

Fig. 5. Variation of Talitrussaltator sex ratio (males/females) at the three study sites.

a cause-and-effect relation, with temperature favouring recruitment and, consequently, the increase in density and biomass. As expected, biomass and population density were also significantly correlated $\left(r^{2}=0.67\right.$, for 30 observations).

The significant positive correlation between the percentage of juveniles in the population (PJ) and temperature $(T)$ appears obviously to be a function of recruitment, which took place in spring and summer, the warmest months in the year, while the positive

Table 1

Average (A) daily values and standard deviation (SD) of physicochemical factors at Lavos beach (western coast of Portugal) during the period March 1999 to June 2000

\begin{tabular}{|c|c|c|c|c|c|c|c|c|c|c|c|c|c|c|c|c|c|c|c|}
\hline \multicolumn{2}{|c|}{$\begin{array}{l}\text { Temperature } \\
\left({ }^{\circ} \mathrm{C}\right)\end{array}$} & \multicolumn{2}{|c|}{$\begin{array}{l}\text { Precipitation } \\
(\mathrm{mm})\end{array}$} & \multicolumn{2}{|c|}{$\begin{array}{l}\text { Sediment } \\
\text { moisture (\%) }\end{array}$} & \multicolumn{2}{|c|}{$\begin{array}{l}\text { Organic matter } \\
\text { content in } \\
\text { sediments }(\%)\end{array}$} & \multicolumn{2}{|c|}{$\begin{array}{l}\text { Detritus } \\
\left(\mathrm{g} \mathrm{m}^{-2)}\right.\end{array}$} & \multicolumn{2}{|c|}{ Wind velocity } & \multicolumn{2}{|c|}{ Cloudiness } & \multicolumn{2}{|c|}{ Visibility } & \multicolumn{2}{|c|}{$\begin{array}{l}\text { Wave } \\
\text { height }\end{array}$} & \multicolumn{2}{|c|}{$\begin{array}{l}\text { Wave } \\
\text { period }\end{array}$} \\
\hline A & $\mathrm{SD}$ & A & SD & A & SD & A & SD & A & SD & A & SD & A & SD & A & SD & A & SD & A & SD \\
\hline 15.65 & 4.77 & 2.41 & 5.63 & 3.24 & 1.22 & 0.15 & 0.05 & 9.15 & 9.03 & 3.92 & 2.98 & 4.06 & 2.67 & 6.05 & 1.05 & 0.05 & 0.32 & 0.11 & 0.65 \\
\hline
\end{tabular}


correlation with sediment moisture basically expresses a non-uniform distribution of juveniles in the beach, with younger individuals, which are probably more sensitive to dehydration, concentrating closer to the water line.

\subsection{Field growth rates and life span}

Size-frequency polymodal distributions were analysed for recognizable cohorts (Figs. 6-8). At Lavos, five cohorts $(1,2,3,4$, and 5) could be identified from data from the first sampling date (24 March 1999) (Fig. 6). From modal analysis, eight new distributions, presumably corresponding to new recruitments, were clearly identified (Fig. 6) ( $\chi^{2}$ and $G$ tests not significant; $P \leq 0.05)$ during a study period of 18 months, respectively, on 7 April (cohort 6), 10 May (cohort 7), 17 June (cohort 8), 21 July (cohort 9), and 3 September (cohort 10), in 1999, and again on 17 March (cohort 11), 29 March (cohort 12), and 19 May (cohort 13), in 2000.

At Collelungo, three cohorts (1, 2, and 3) were recognized at the first sampling date (9 February 1999) (Fig. 7), and eight new cohorts were detected and tracked during the next 12 months, which was the duration of the study period in Italy, respectively, on 8 April (cohort 4), 7 May (cohort 5), 7 June (cohort 6), 6 July (cohort 7), 20 July (cohort 8), 3 August (cohort 9), 3 September (cohort 10), and 17 September 1999 (cohort 11) (Fig. 7). From results of modal analysis, the number of new recruitments in the Italian population is higher than in the Atlantic population during the same period. Therefore, although cohort recognition was still possible, the Italian population approximated more closely to continuous breeding during the reproductive period.

Finally, at Zouara, four cohorts (1, 2, 3, and 4) were recognized at the first sampling date (2 December 1998), and six new distributions were identified during a study period of 12 months, respectively, on 20 February (cohort 5), 29 April (cohort 6), 2 June (cohort 7), during the period between 21 July and 2 October (cohorts 8 and 9), and 10 November 1999 (cohort 11) (Fig. 8).

Size of cohorts at the moment of detection (minimal size) varied as a function of study sites (Fig. 9). At Lavos, the minimum average $\mathrm{CL}$ of new cohorts ranged from 0.4901 to $0.5511 \mathrm{~mm}$ (3.59-4.26 mm TL), while the maximum average $\mathrm{CL}$ ranged from 1.48 to $1.78 \mathrm{~mm}$ (14.37-17.64 mm TL). At Collelungo, the minimum average CL ranged from 0.38 to $0.45 \mathrm{~mm}$ (3.86$4.48 \mathrm{~mm} \mathrm{TL}$ ), and the maximum values ranged from 1.23 to $1.38 \mathrm{~mm}(11.36-12.69 \mathrm{~mm} \mathrm{TL})$. Finally, at Zouara, the minimum average $\mathrm{CL}$ ranged between 0.41 and $0.57 \mathrm{~mm}(3.92-5.39 \mathrm{~mm} \mathrm{TL})$, and the maximum ranged from 1.34 to $1.72 \mathrm{~mm}$ (12.41-15.88 mm TL). On average, the population presenting the largest adults was that of Lavos (Atlantic), while the smallest individuals came from the Collelungo population (Italy), with individuals from the Zouara population (Tunisia) ranging in the middle. Nevertheless, taking into account the equations relating data on $\mathrm{CL}$ and $\mathrm{TL}$ given previously, newborn individuals from the two Mediterranean populations appeared slightly larger in TL than the ones from the Atlantic population.

Growth was found to be continuous across the life span of Talitrus saltator, although growth rates varied with size and temperature. Growth rates were faster in the early phases, and appeared to be higher during spring and summer (Fig. 9). This pattern was recognizable at Lavos and Collelungo, although it was less clear at Zouara. Taking into consideration growth rates and the disappearance of cohorts, life span was estimated at 7-11 months at Lavos, 6-9 months at Collelungo, and 6-8 months at Zouara (Table 2). As a general pattern, at the three sites, cohorts born at the beginning of the reproductive period tend to have shorter lives than those born later in the season. The longer life spans were observed in cohorts that over-wintered and bred in the next reproductive period (Fig. 9).

Growth data sets from the three sites were used to calibrate the growth model proposed by Bertalanffy (1957), providing a different set of parameters in each case. Growth data fitted the model well, with faster growth rates in the early phases (Fig. 10). Based on the model, the minimum period necessary for male sexual differentiation after birth was estimated at \pm 4 weeks at Lavos, \pm 3 weeks at Collelungo, and \pm 4.5 weeks at Zouara. Regarding female sexual differentiation, the same period was estimated at \pm 6 weeks at Lavos, and \pm 5 weeks at Collelungo and Zouara. Finally, the period necessary for female sexual maturation after birth was estimated at \pm 10 weeks at Lavos, and \pm 8 weeks at Collelungo and Zouara (Table 2). Sexual differentiation tends, therefore, to occur earlier in males than in females. Moreover, although the output from the model, calibrated with data from Zouara, provided some unexpected results regarding male sexual differentiation, there is a suggestion, at least in females, that sexual differentiation occurs later after birth in Atlantic populations in comparison with the Mediterranean.

\subsection{Life cycle}

Size-frequency analysis (Figs. 6-8) allowed determination of the cohorts to which males and gravid females belonged, and thus to assess their contributions to recruitment. Parental relations between existing cohorts and new ones that arrived in the population during the study period could therefore be interpreted, permitting the comparison of the three populations that were studied with regard to life cycle characteristics (Fig. 11).

Cohorts born early in the reproductive period, i.e. spring, at Lavos and Collelungo, and late winter/early spring at Zouara, will, in principle, still reproduce in 

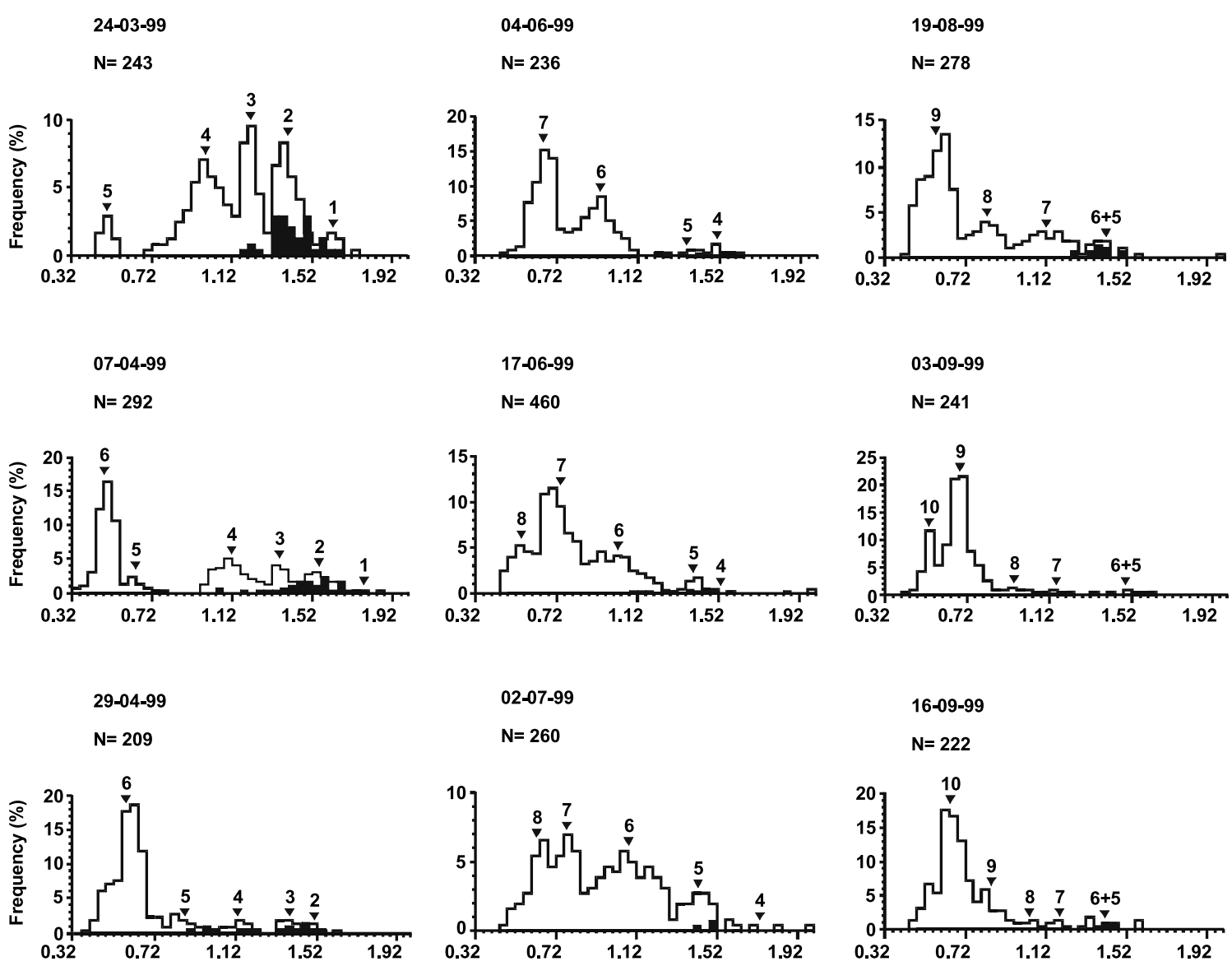

02-07-99

$\mathrm{N}=\mathbf{2 6 0}$

16-09-99

$\mathbf{N}=\mathbf{2 2 2}$
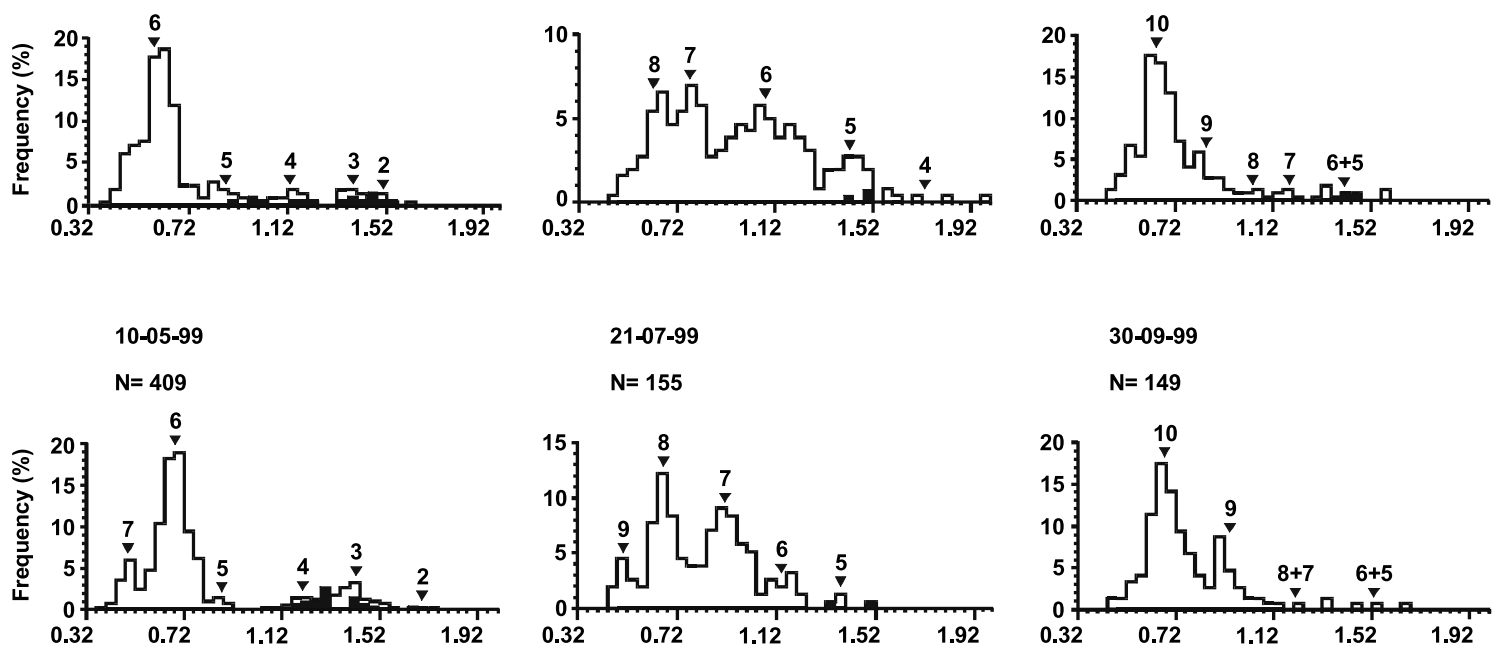

21-07-99

30-09-99

$\mathbf{N}=155$

$\mathrm{N}=149$
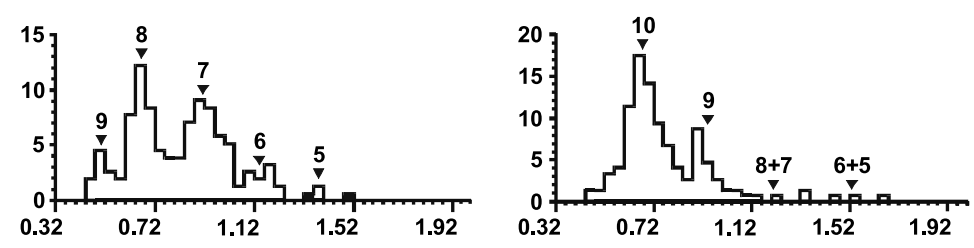

21-05-99

02-08-99

03-11-99

$\mathbf{N}=\mathbf{3 8 9}$

$\mathbf{N}=\mathbf{2 1 9}$

$\mathrm{N}=135$
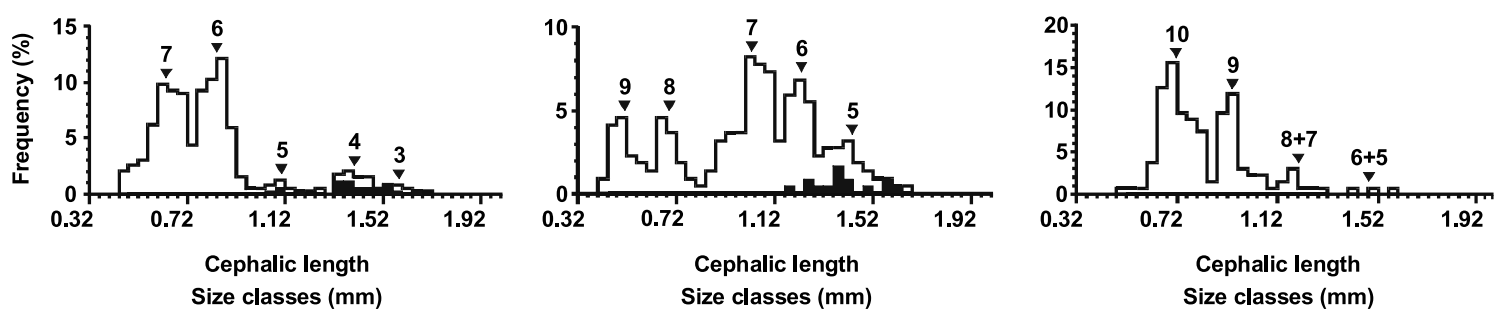

Fig. 6. (a) Size-frequency distribution of Talitrus saltator at Lavos (Portugal) from 24 March to 3 November 1999. Sampling dates are indicated. $N$, number of measured individuals. Arrowheads indicate average CL of the numbered cohorts or groups of cohorts. Black areas indicate gravid females. (b) Size-frequency distribution of T. saltator at Lavos (Portugal) from 16 November 1999 to 16 June 2000. 


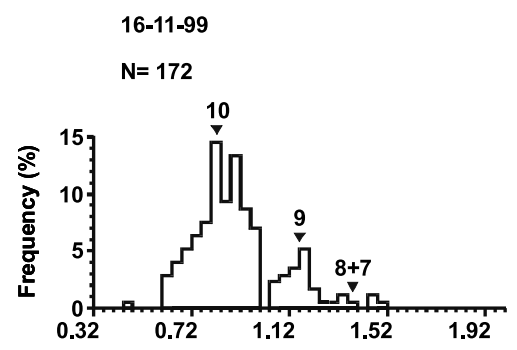

02-02-00

$\mathrm{N}=119$

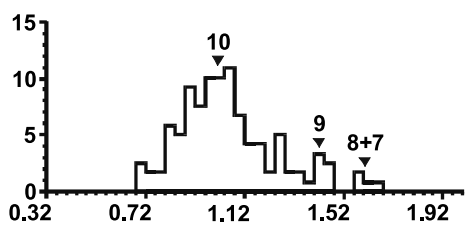

$30-11-99$

$\mathrm{N}=\mathbf{2 1 8}$

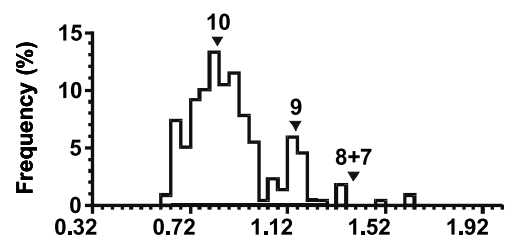

17-12-99

$\mathrm{N}=113$

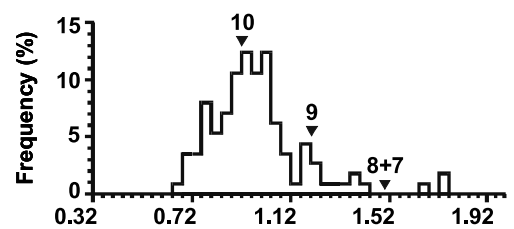

04-01-00

$\mathbf{N}=\mathbf{1 8 0}$

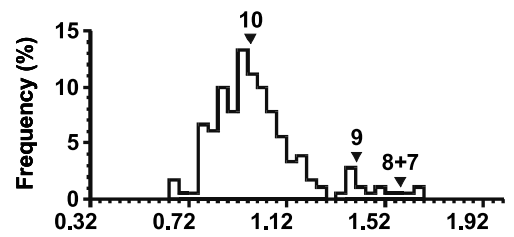

20-01-00

$\mathrm{N}=59$

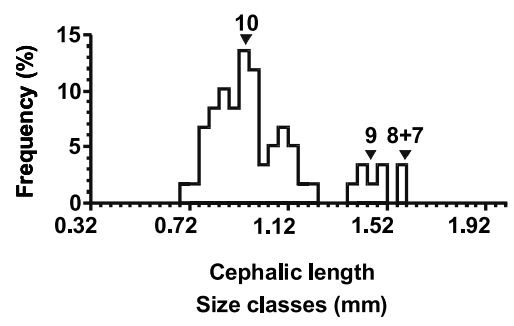

16-02-00

$\mathrm{N}=\mathbf{2 0 8}$

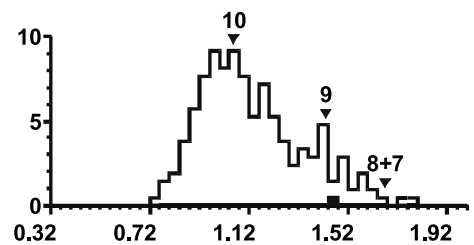

01-03-00

$\mathrm{N}=\mathbf{2 9 7}$

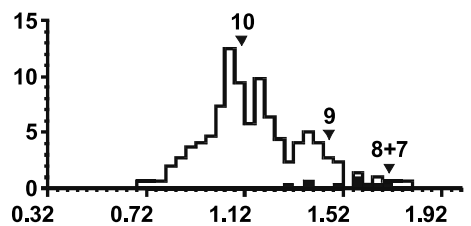

17-03-00

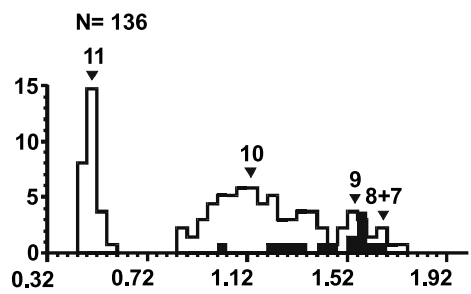

29-03-00

$\mathrm{N}=186$

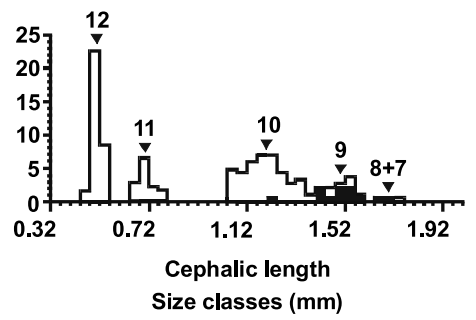

17-04-00

$N=208$

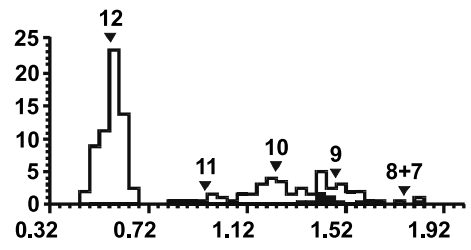

03-05-00

$\mathrm{N}=\mathbf{4 1 6}$

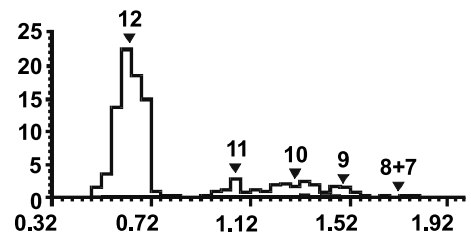

19-05-00

$N=145$

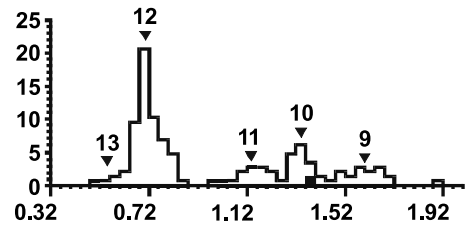

02-06-00

$\mathrm{N}=172$

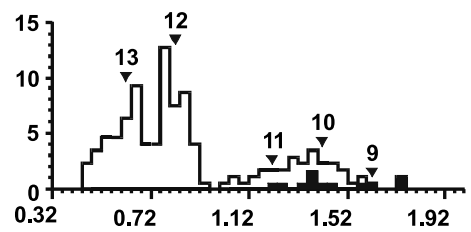

16-06-00

$\mathbf{N}=319$

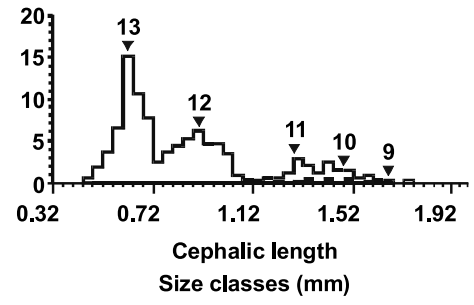

Fig. 6 (continued)

the same season, but will live less and, most probably, will not survive the winter. On the other hand, cohorts born later in the reproductive period, i.e. summer or early autumn, will live longer, going through winter, becoming sexually active and breeding only in the next reproductive period. Despite differences between the three study sites, this constitutes a consistent pattern. Therefore, it may be concluded that all the studied 
9-2-99

$\mathrm{N}=77$

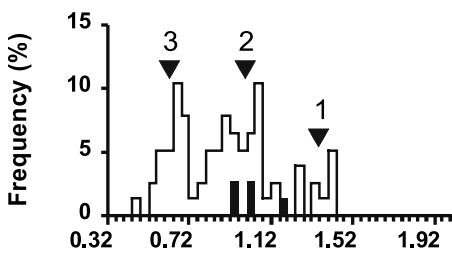

24-2-99

$\mathrm{N}=77$

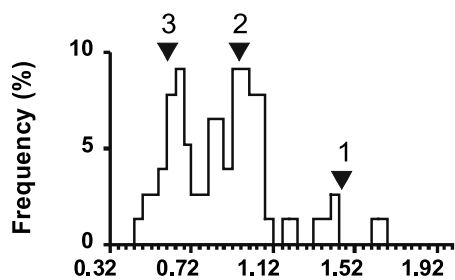

9-3-99

$\mathrm{N}=65$

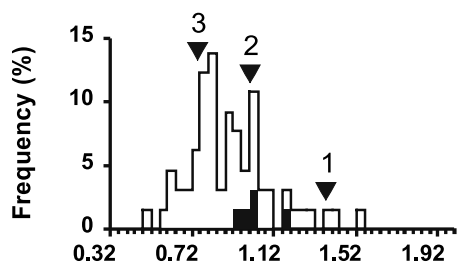

23-3-99

$\mathrm{N}=162$

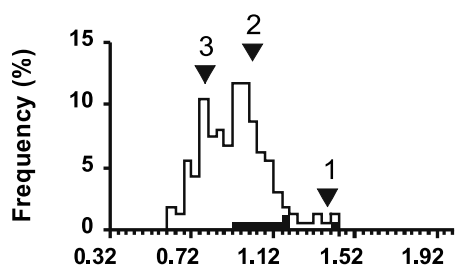

Cephalic length Size classes $(\mathrm{mm})$
8-4-99

$\mathrm{N}=63$

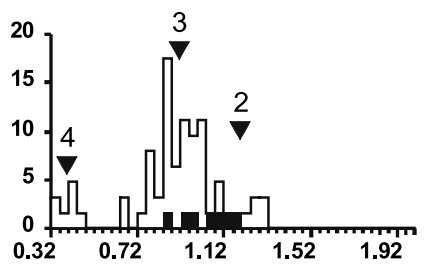

21-4-99

$\mathrm{N}=131$

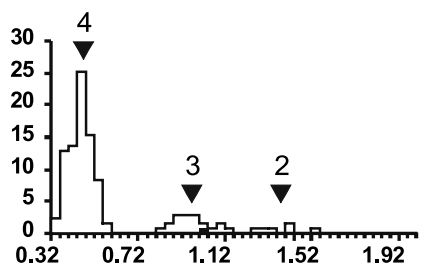

7-5-99

$\mathrm{N}=261$

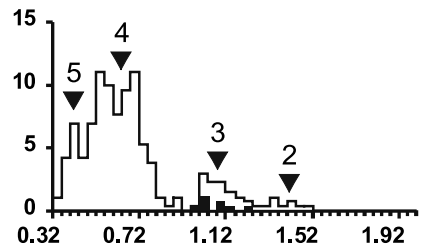

20-5-99

$\mathrm{N}=308$

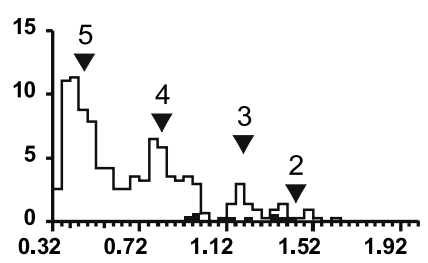

Cephalic length Size classes $(\mathrm{mm})$
7-6-99

$\mathrm{N}=\mathbf{2 4 0}$

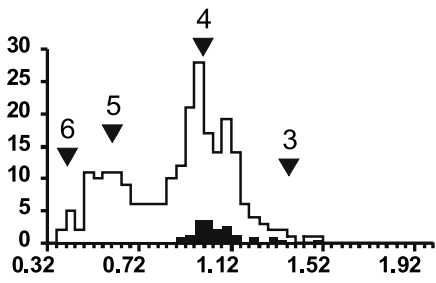

21-6-99

$\mathrm{N}=162$

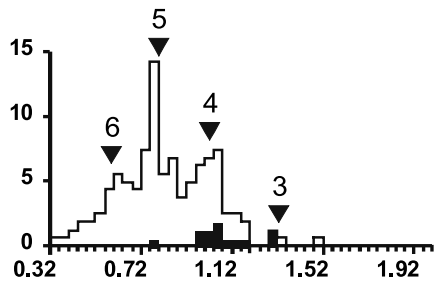

6-7-99

$\mathrm{N}=\mathbf{2 0 4}$

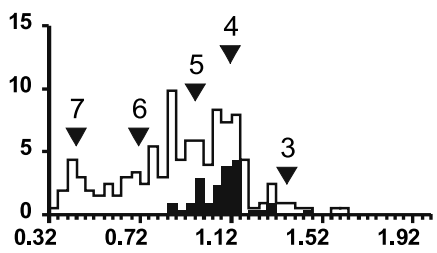

20-7-99

$\mathrm{N}=\mathbf{2 6 8}$

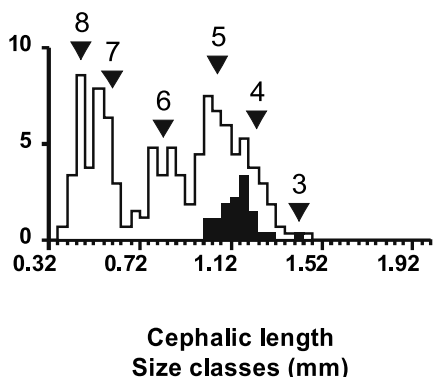

Fig. 7. (a) Size-frequency distribution of Talitrus saltator at Collelungo (Italy) from 9 February to 20 July 1999. (b) Size-frequency distribution of T. saltator at Collelungo (Italy) from 3 August to 12 December 1999.

populations produced two generations within the same reproductive period. Moreover, taking into account the probable parental relations between existing cohorts and new ones (Fig. 11), it appears that females from each cohort breed at least twice.
It seems, therefore, that at the studied sites, Talitrus saltator is a semiannual species, with iteroparous females appearing to produce at least two broods per year, and has a bivoltine life cycle, since the populations produce two generations per year (Table 2). 
3-8-99

$\mathrm{N}=132$
17-9-99

$\mathrm{N}=199$

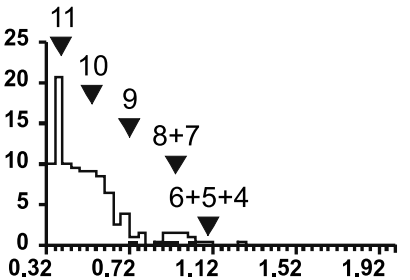

1-10-99

$\mathrm{N}=167$

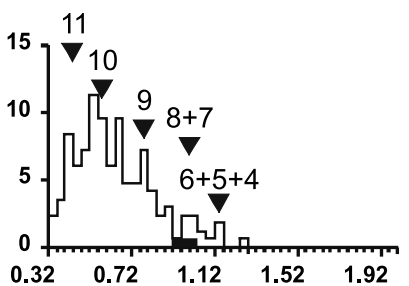

2-11-99

$\mathrm{N}=181$

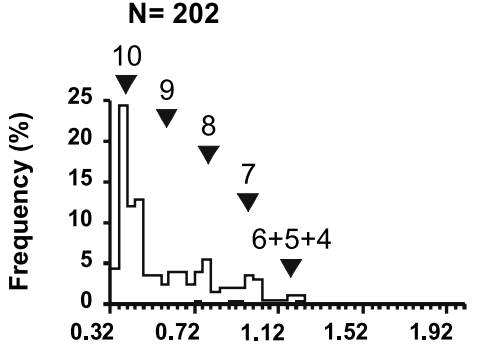

Cephalic length

Size classes $(\mathrm{mm})$
Cephalic length Size classes $(\mathrm{mm})$

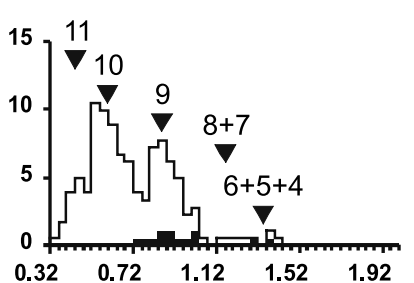

16-11-99

$\mathrm{N}=154$

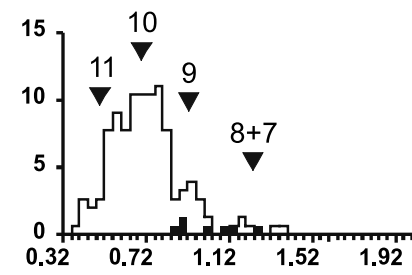

1-12-99

$\mathrm{N}=168$

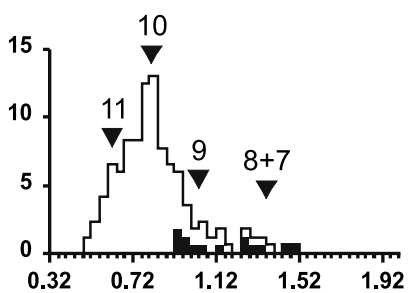

13-12-99

$\mathrm{N}=27$

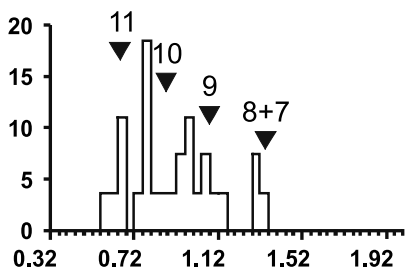

Cephalic length Size classes $(\mathrm{mm})$

Fig. 7 (continued)

\subsection{Production estimates}

Length-weight relationships previously established were used in production estimates (see Section 2). Growth production $(P)$ was estimated at $0.74 \mathrm{~g} \mathrm{~m}^{-2} \mathrm{yr}^{-1}$ AFDW at Lavos, $0.12 \mathrm{~g} \mathrm{~m}^{-2} \mathrm{yr}^{-1}$ AFDW at Collelungo, and $0.61 \mathrm{~g} \mathrm{~m}^{-2} \mathrm{yr}^{-1}$ AFDW at Zouara, which for talitrids is approximately equivalent, respectively, to $17.7,2.8$, and $14.3 \mathrm{~kJ} \mathrm{~m}^{-2} \mathrm{yr}^{-1}$ (Jørgensen, Nielsen, \& Jørgensen, 1991). Elimination production $(E)$ was estimated at $1.40 \mathrm{~g} \mathrm{~m}^{-2} \mathrm{yr}^{-1}$ AFDW $\left(33.5 \mathrm{~kJ} \mathrm{~m}^{-2} \mathrm{yr}^{-1}\right)$ at Lavos, $0.20 \mathrm{~g} \mathrm{~m}^{-2} \mathrm{yr}^{-1}$ AFDW $\left(4.8 \mathrm{~kJ} \mathrm{~m}^{-2} \mathrm{yr}^{-1}\right)$ at Collelungo, and $1.11 \mathrm{~g} \mathrm{~m}^{-2} \mathrm{yr}^{-1}$ AFDW $\left(26.6 \mathrm{~kJ} \mathrm{~m}^{-2}\right.$ $\mathrm{yr}^{-1}$ ) at Zouara (Table 2). The average annual biomass $(\bar{B})$ (standing stock) was estimated at $0.13 \mathrm{~g} \mathrm{~m}^{-2}$ at Lavos, $0.014 \mathrm{~g} \mathrm{~m}^{-2}$ at Collelungo, and $0.084 \mathrm{~g} \mathrm{~m}^{-2}$ at
Zouara, resulting in $P / \bar{B}$ ratios of 5.7 at Lavos, 8.2 at Collelungo, and 7.3 at Zouara, and $E / \bar{B}$ ratios of 10.8 at Lavos, 14.4 at Collelungo, and 13.1 at Zouara (Table 2).

The analysis of the temporal variation of growth and elimination productions at the three study sites (Fig. 12) show that at Lavos and Collelungo, the highest values of growth production $(P)$ were observed during spring and summer, as one should expect. At Zouara, however, the highest values were recorded in late winter and early spring, becoming extremely low throughout the summer. As for elimination production $(E)$ at Lavos and Collelungo, values increased during spring and summer periods, but were also augmented during winter, while at Zouara, there was a clear peak from January to April, and again a small increase in autumn. 

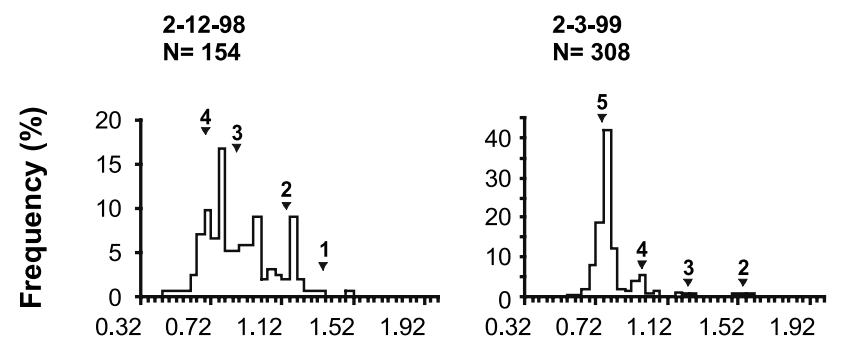

14-5-99 $\mathrm{N}=5$

\section{7-1-99 \\ $\mathrm{N}=169$}

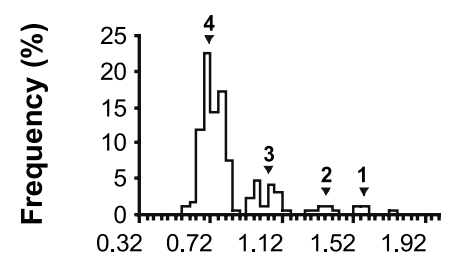

7-2-99

$\mathrm{N}=181$

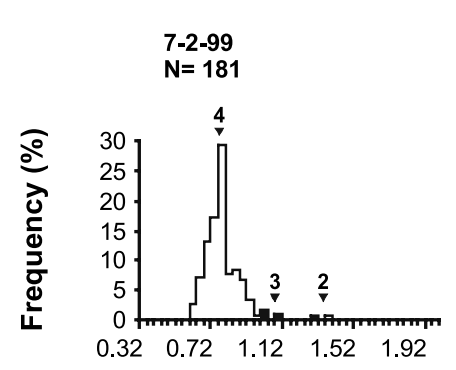

16-3-99

$\mathrm{N}=132$

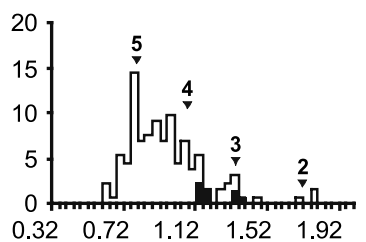

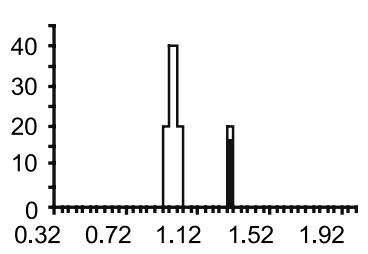
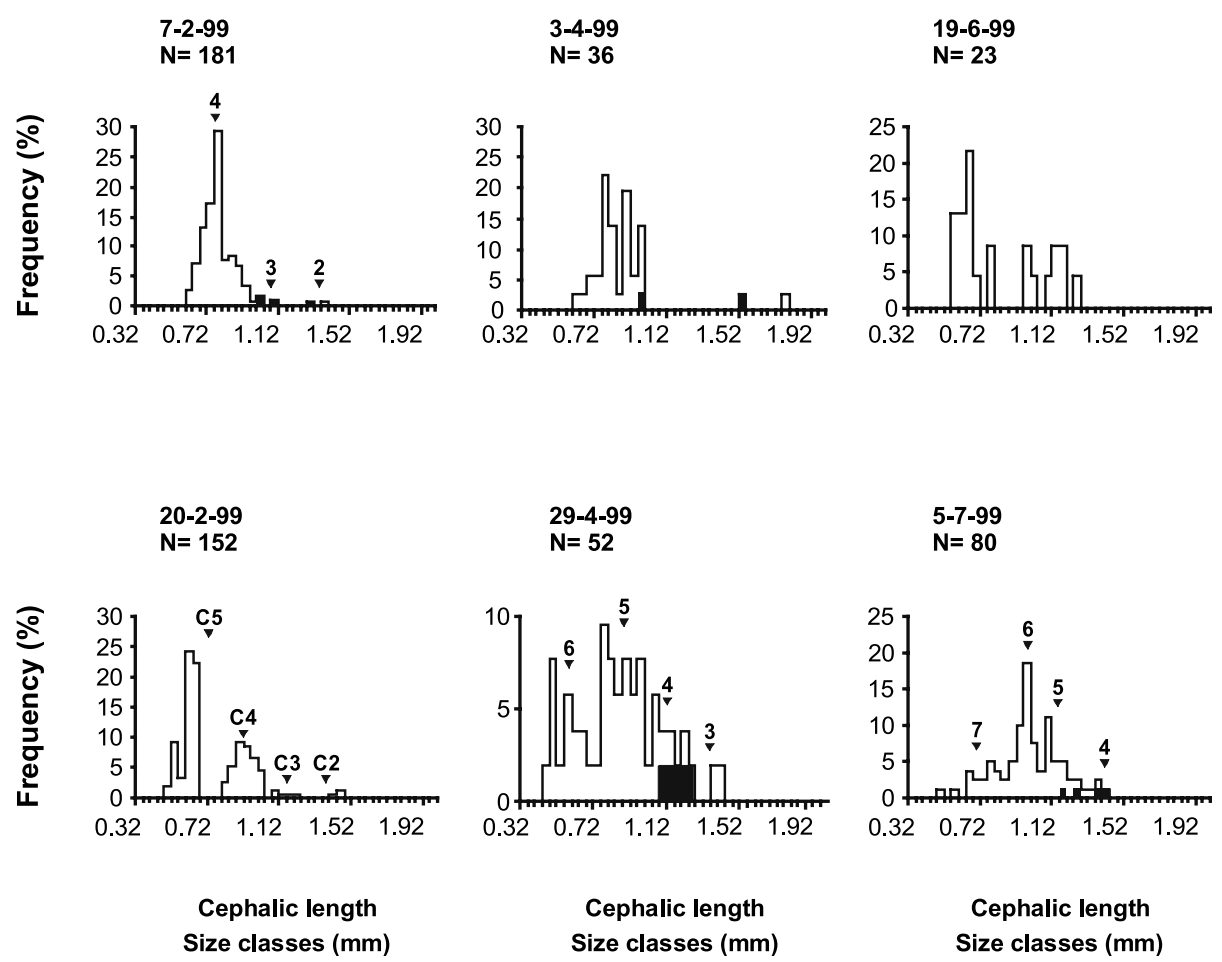

Size classes $(\mathrm{mm})$

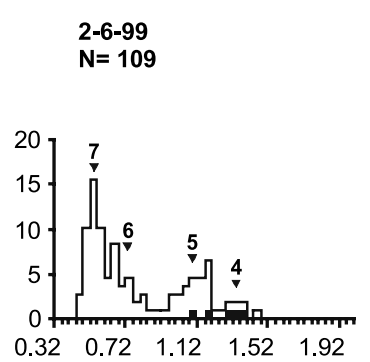

Fig. 8. (a) Size-frequency distribution of Talitrus saltator at Zouara (Tunisia) from 2 December 1998 to 7 July 1999. (b) Size-frequency distribution of T. saltator at Zouara (Tunisia) from 21 July to 6 December 1999.

\section{Discussion}

\subsection{Spatial distribution and population abundance}

Talitrus saltator showed a pattern of aggregated distribution at all the three sites. Talitrids are usually associated with freshly deposited wrack (Marsden, 1991b), which was confirmed with regard to T. saltator. This patchiness is evident at small spatial scales, e.g. of the order of $0.25 \mathrm{~m}^{-2}$, but becomes diluted at larger scales, since no significant correlation was found between population density and drift material biomass 

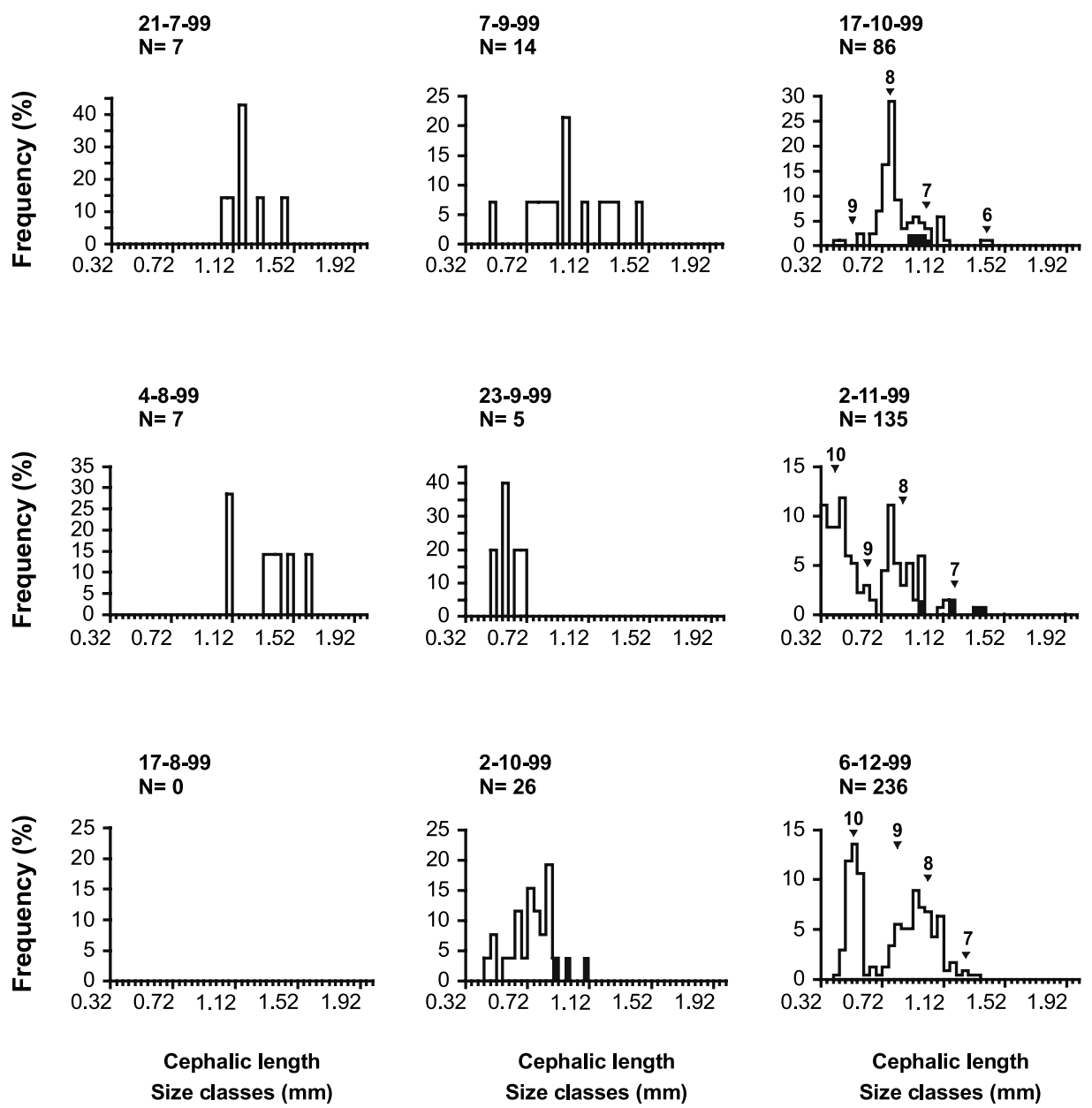

Fig. 8 (continued)

when account was taken of the whole set of replicates collected at each date. This is consistent with observations on Talorchestia quoyana in New Zealand, where no connection was found between density and kelp biomass, although spatial distribution was dependent on the availability of drift wrack (Marsden, 1991a,b).

Population densities were consistently higher at Lavos, in comparison with the two Mediterranean beaches. If, as in other talitrids (Pennings et al., 2000), the feeding preferences of Talitrus saltator at the three sites are basically similar, and if the debris has a similar value as food, the most probable explanation for the observed differences in density is the availability of drift wrack. In the Mediterranean, wrack supply to beaches depends on storms, while in the Atlantic coasts, the tides may provide more regular supply, twice a day.

The pattern of variation of population abundance was very similar at Lavos and Collelungo, and clearly different at Zouara. The present results suggest that differences observed could be explained by a major displacement of Talitrus saltator from the beach to the dunes during the hotter months, while Talorchestia brito, a sympatric species at Lavos and Zouara, would tend to move from the dunes to the beach. Such interpretation would be consistent with results from other authors regarding burrowing and surface migration as behavioural responses to variations in temperature and sand moisture (Morritt, 1998; Tsubokura, Goshima, \& Nakao, 1997). Besides, it would also be supported by the fact that $T$. brito reaches the highest densities in the beach precisely during spring and summer (Fig. 13), suggesting a combination of interspecific competition and behavioural plasticity. However, a sound explanation for the observed variation of population abundance is not available, and there is an apparent contradiction with the observations reported by Charfi-Cheikhrouha, ElGtari, and Bouslama (2000), which suggested that $T$. saltator tends to migrate from the dune to the shoreline in spring.

Spatial and temporal behavioural plasticities between the sympatric species, Talitrus saltator and Talorchestia brito, in relation to air humidity, sand temperature and moisture, atmospheric pressure, and tidal elevation were observed in French Atlantic beaches (Fallaci et al., 

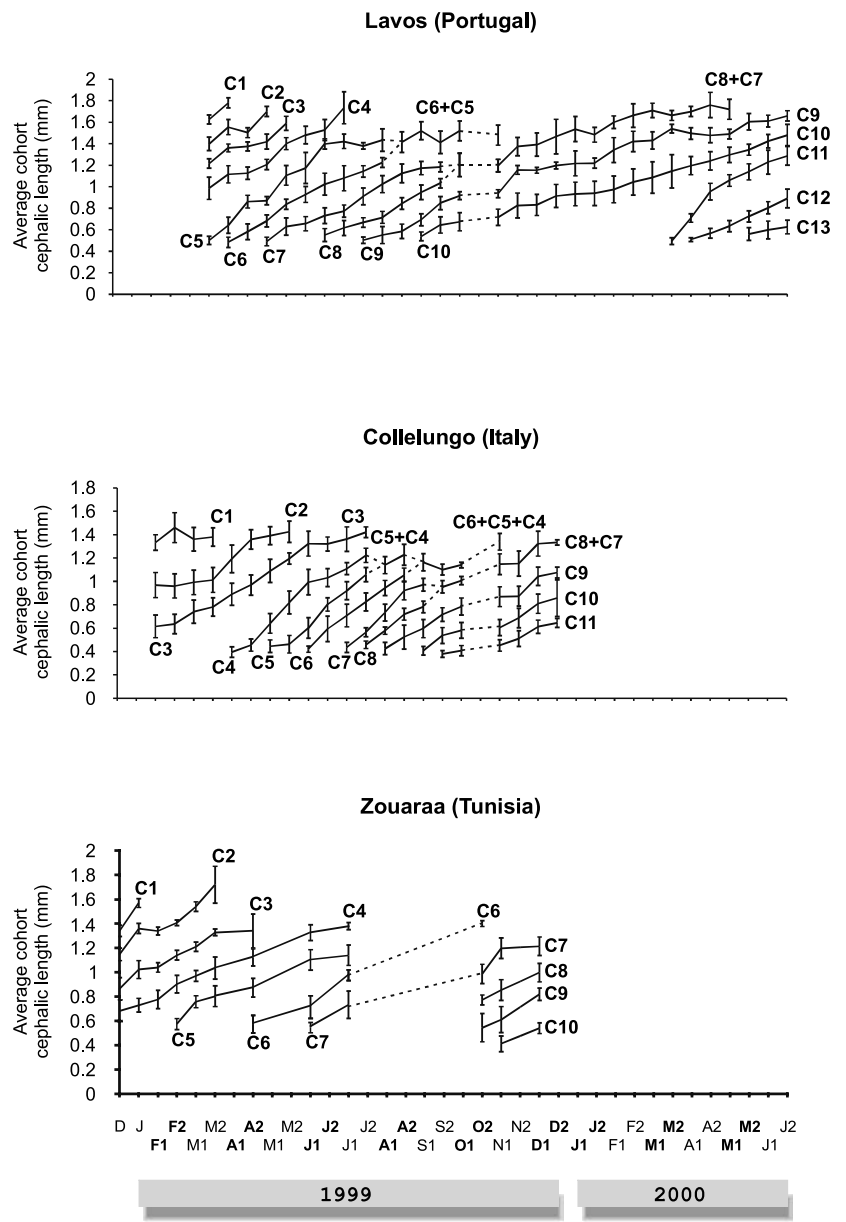

Fig. 9. Estimated growth and life span (field growth data) of Talitrus saltator cohorts or groups of cohorts (average $\mathrm{CL} \pm$ standard deviation) at the three study sites. Broken lines indicate probable cohort merging or cohort evolution through time.
1999), and at the Zouara beach (Colombini et al., 2002; Scapini et al., 2002). The role of vertical separation in the litter as a factor avoiding inter-specific competition between Talitrus and Orchestia species from Tasmania has also been described (Richardson, 1993; Richardson \& Devitt, 1984). Ecophysiological responses in regulating the talitrids spatial distribution and inter-specific competition are of obvious importance (Morrit \& Spicer, 1999). For instance, species that lose more water through the gills have more constraints in terms of their spatial distribution on sandy beaches, being limited to areas of relatively higher humidity. This is illustrated by the spatial competition between Talorchestia quoyana and Transorchestia chiliensis from New Zealand (Marsden, 1991c), and the difference in distribution between $T$. saltator and $T$. brito may be similarly explained. On the other hand, the role of burrowing and surface migration as behavioural responses to variations in temperature and sand moisture as been described for Trinorchestia trinitatis from Japan (Tsubokura et al., 1997), and some authors are of the opinion that behavioural adaptations to potentially desiccating conditions are more important than physiological mechanisms to reduce water loss (e.g. Hazlett, 1988). The fact that T. saltator is almost the only talitrid species at Lavos and Collelungo (approximately $90 \%$ of the individuals collected), while at Zouara, it occurs together with the sympatric $T$. brito, supports the suggestion that a combination of inter-specific competition and behavioural plasticity constitutes the most probable explanation for differences observed in the distribution of population abundance.

Table 2

Comparison of Talitrus saltator population's characteristics at different sites with regard to biology, life cycle, and reproduction

\begin{tabular}{|c|c|c|c|c|}
\hline Characteristics & $\begin{array}{l}\text { Isle of Man } \\
\text { (UK) Atlantic }\end{array}$ & $\begin{array}{l}\text { Lavos (Portugal) } \\
\text { Atlantic }\end{array}$ & $\begin{array}{l}\text { Collelungo (Italy) } \\
\text { Mediterranean }\end{array}$ & $\begin{array}{l}\text { Zouara (Tunisia) } \\
\text { Mediterranean }\end{array}$ \\
\hline Reproductive period & May to late August & March-September & April-September & February-October \\
\hline Average sex ratio $(+/ \widehat{)})$ & $0.69: 1$ & $1.2: 1$ & $1.04: 1$ & $0.54: 1$ \\
\hline $\begin{array}{l}\text { Age of males at sexual } \\
\text { differentiation (weeks) }\end{array}$ & $12-16$ & \pm 4 & \pm 3 & \pm 4.5 \\
\hline $\begin{array}{l}\text { Age of females at sexual } \\
\text { differentiation (weeks) }\end{array}$ & $12-16$ & \pm 6 & \pm 5 & \pm 5 \\
\hline $\begin{array}{l}\text { Age of females at sexual } \\
\text { maturation (weeks) }\end{array}$ & - & \pm 10 & \pm 8 & \pm 8 \\
\hline Life span (months) & $18-21$ & $7-11$ & $6-9$ & $6-8$ \\
\hline Recruitment pattern & Univoltine & Bivoltine & Bivoltine & Bivoltine \\
\hline $\begin{array}{l}\text { Growth production }(P) \\
\quad\left(\mathrm{g} \mathrm{m}^{-2} \mathrm{yr}^{-1}\right)\end{array}$ & - & 0.74 & 0.115 & 0.61 \\
\hline $\begin{array}{l}\text { Elimination production }(E) \\
\left(\mathrm{g} \mathrm{m}^{-2} \mathrm{yr}^{-1}\right)\end{array}$ & - & 1.40 & 0.20 & 1.11 \\
\hline $\begin{array}{l}\text { Average annual biomass }(B) \\
\left(\mathrm{g} \mathrm{m}^{-2}\right)\end{array}$ & - & 0.13 & 0.014 & 0.084 \\
\hline$P / B$ & $2.47-2.93^{\mathrm{b}}$ & 5.7 & 8.2 & 7.3 \\
\hline$E / B$ & - & 10.8 & 14.4 & 13.1 \\
\hline
\end{tabular}

${ }^{a}$ Based on data produced in the present study and from Williams (1978).

b Estimated according to Wildish (1984, 1988 in O'Hanlon \& Bolger, 1997). 

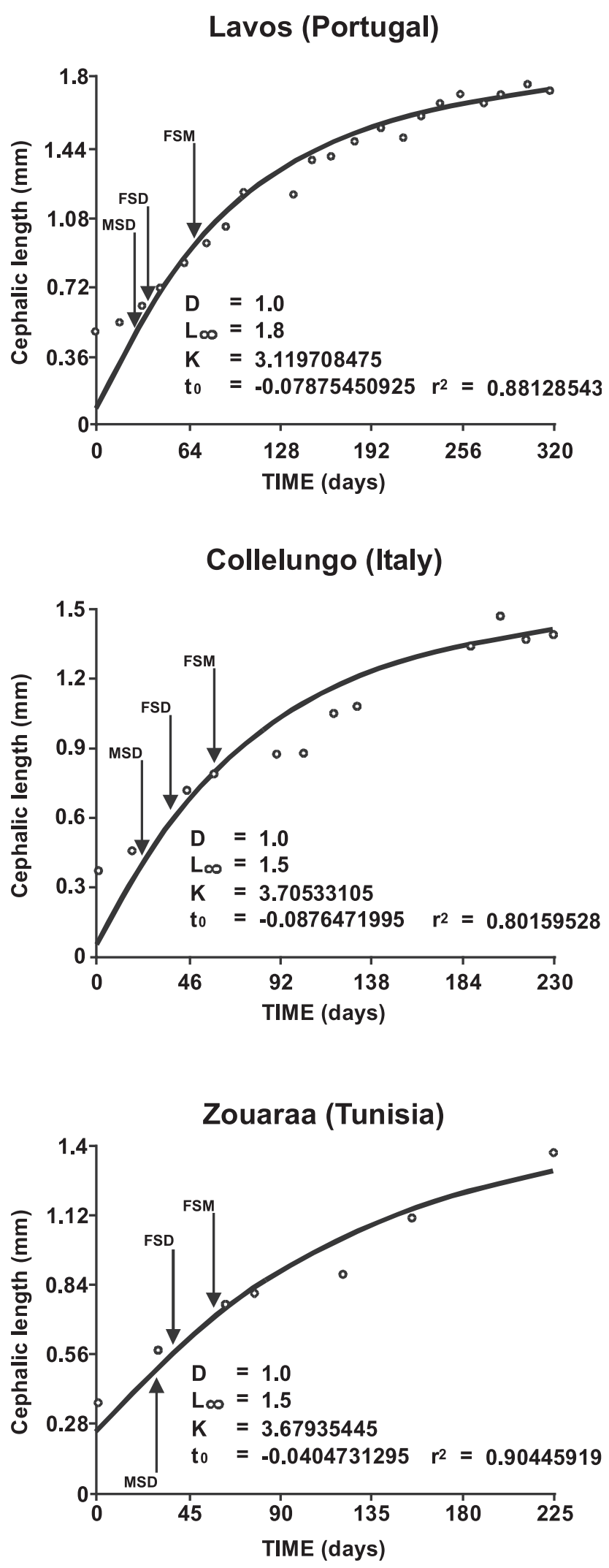

Fig. 10. Individual growth model (Bertalanffy, 1957) of Talitrus saltator at the three study sites. The models were calibrated with field growth data from cohorts or groups of cohorts (plotted points). Model parameters are given; $r^{2}$, correlation between predicted and observed values (see Section 2 for details). MSD, male's sexual differentiation; FSD, female's sexual differentiation; FSM, female's sexual maturation.

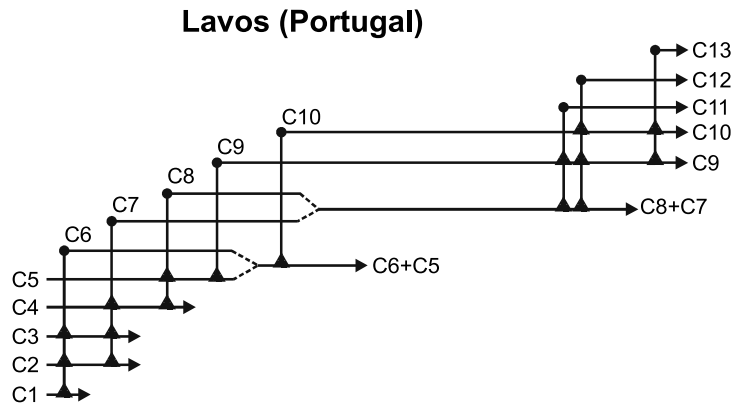

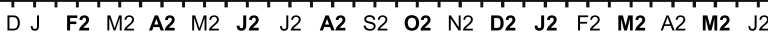

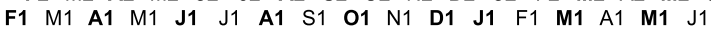

1999

2000

\section{Collelungo (Italy)}

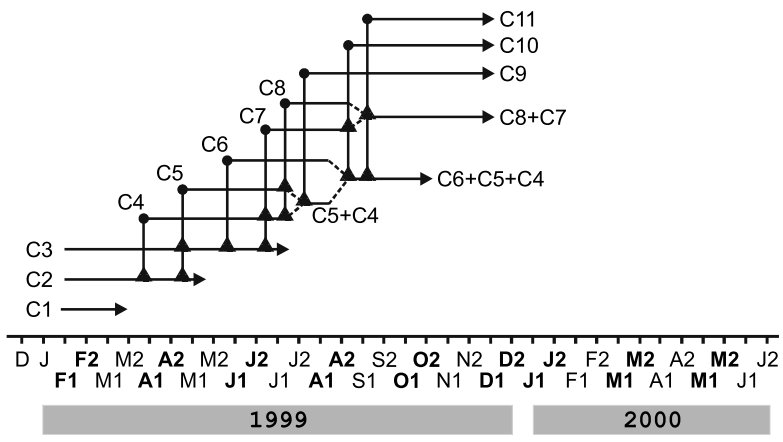

Zouaraa (Italy)

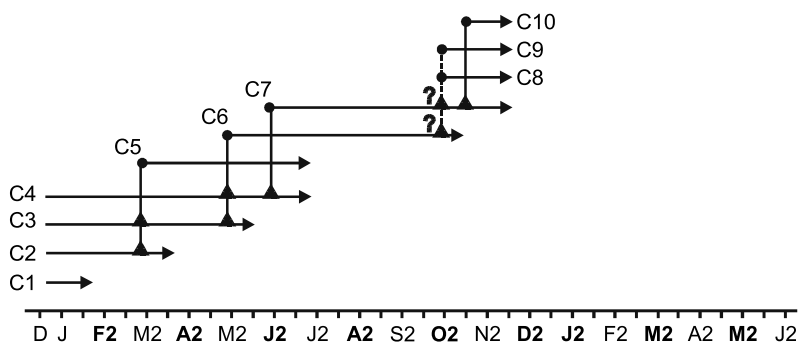

Fig. 11. Analysis of the recruitment pattern of Talitrus saltator at the three study sites. The horizontal arrows represent the period during which each cohort was followed during the study period, starting in the solid circles. The assumed contributions of each cohort or group of cohorts are indicated (triangles).

\subsection{Recruitment and sex ratio}

Recruitment took place from early March to late September at Lavos and Collelungo, and from late February to early November at Zouara, corresponding to the longer reproductive period at the southern most study site. In the British Isles, farther to the north, Talitrus saltator reproduction occurs from May to late August (Williams, 1978). To our knowledge, the two data sets represent the only available information on the annual patterns of reproduction of $T$. saltator. A geographical pattern of variation emerges, with shorter 

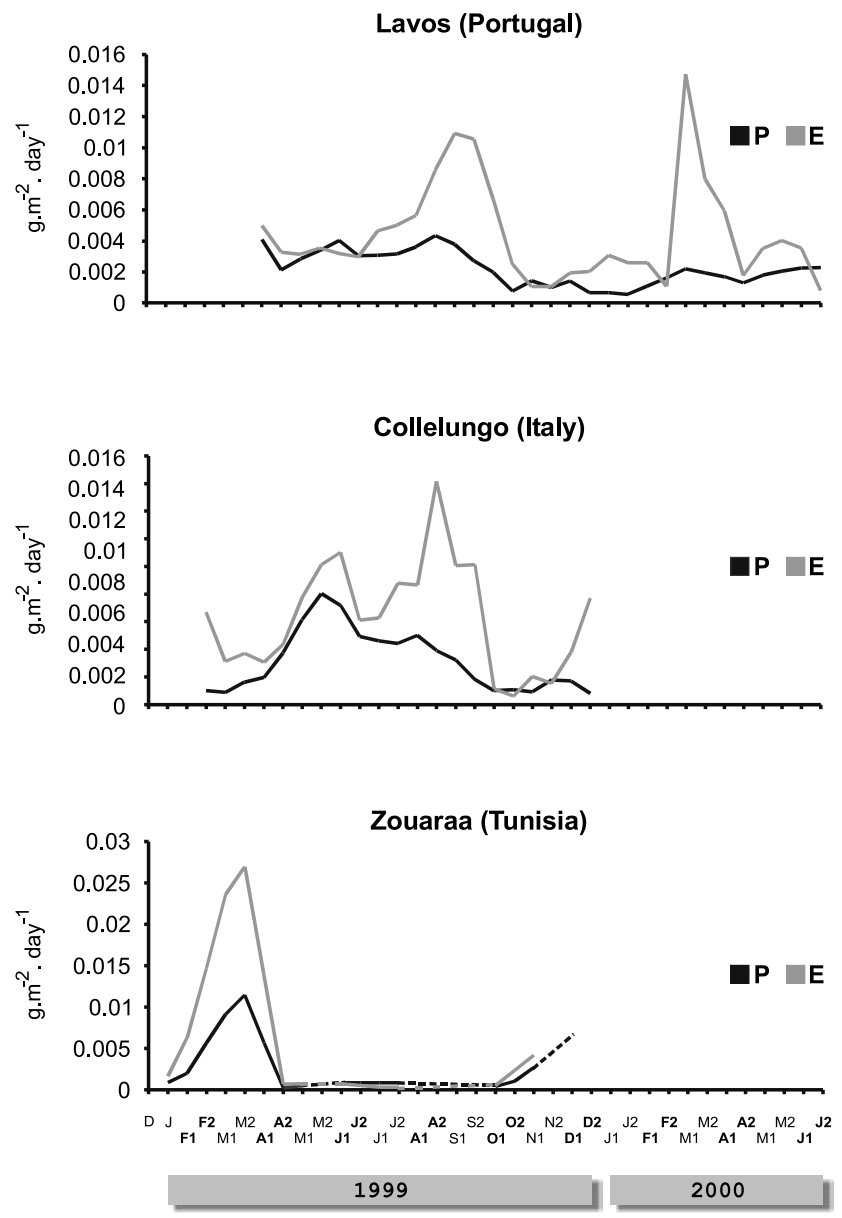

Fig. 12. Analysis of the temporal variation of growth $(P)$ and elimination $(E)$ productions at the three study sites.

recruitment periods in the north and longer in the south, which points towards temperature and photoperiod as major factors controlling gonadal maturation and the duration of the reproductive period (cf. Bregazzi \& Naylor, 1972; Williamson, 1951b). In this regard, data on $T$. saltator are fully consistent with the pattern of geographical variation known among other talitrid species. For instance, Orchestia gammarellus reproduces from May to September, in the Baltic (Persson, 1999, 2001), and from April to August in southwestern British Isles (Cornwall) (Jones \& Wigham, 1993). Closer to the equator, talitrids tend to reproduce through the year, e.g. Pseudorchestoidea brasiliensis, in Brazil (Rio de Janeiro) (Cardoso \& Veloso, 1996), or Talorchestia quoyana, in New Zealand (Marsden, 1991b). These results with $T$. saltator reinforce the idea that large-scale distribution patterns do not correspond to 'fixed' species physiology, as already suggested by Kevin and Spicer (1998) for O. gammarellus.

During most of the study period, the sex ratio was favourable to males at Lavos and Collelungo, with male's proportion in the population decreasing just before the stronger recruitment periods. This might eventually be explained by wearing out of males in relation to reproductive activity, namely pre-copula, or perhaps by the displacement of females from the dunes to the beach. This second possibility is speculative, since no direct evidence of changes in zonation was ever found between males and females, although Marchetti and Scapini (2002) observed differences in orientation between males and females at Zouara. This contrasts with what was observed at Zouara where, with the exception of December 1999, females were dominant in the population. A sex ratio favourable to females appears to be the most common situation among talitrid populations, e.g. in Orchestia gammarellus (Jones \& Wigham, 1993; Persson, 1999), Peudorchestoidea brasiliensis (Cardoso \& Veloso, 1996), or Talitrus saltator (Williams, 1978). The reason for this sex ratio is unclear. In sandy beach-dune systems, a non-homogenous distribution of the two sexes between the beach and the dunes might occasionally explain the differences observed. Parasitic infestation by Paramarteilia orchestiae,

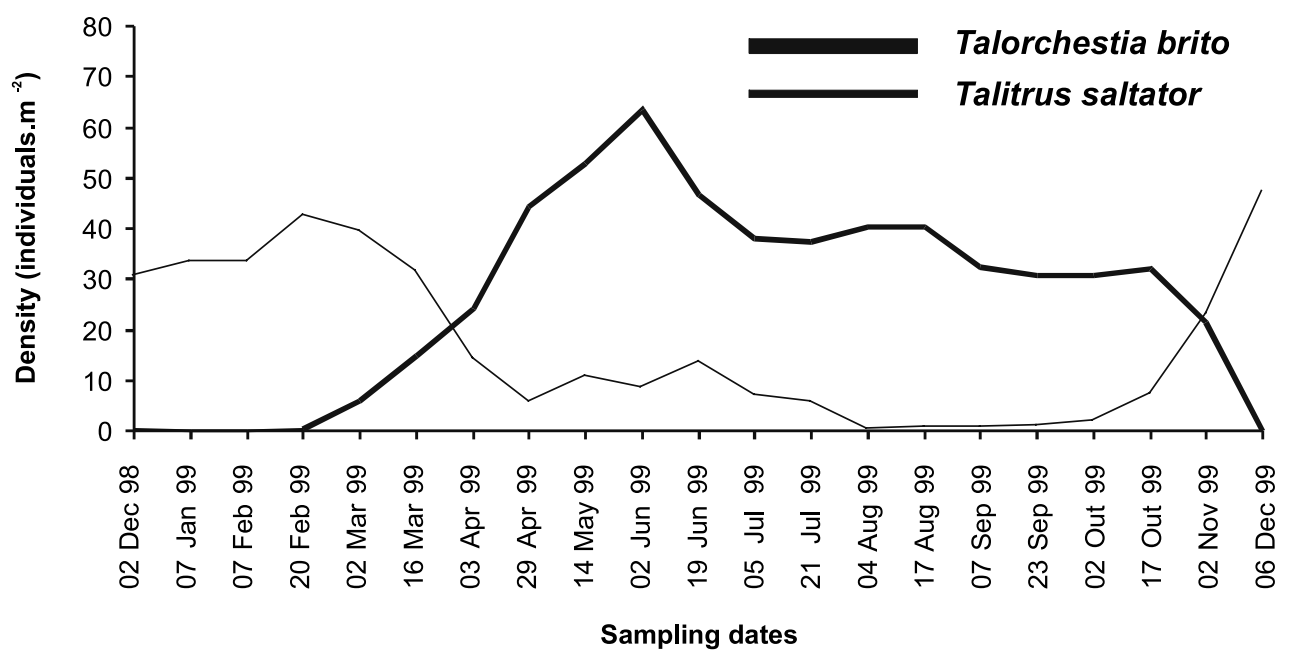

Fig. 13. Variation in population density of Talitrus saltator and Talorchestia brito at Zouara (Tunisia) from 2 December 1998 to 6 December 1999. 
a trans-ovarilly transmitted parasite, has also been identified as a possible cause of sex ratio deviations towards male dominance in $O$. gammarellus, Orchestia mediterranea, and Orchestia aestuarensis from European Atlantic and Mediterranean coasts (Ginsburger-Vogel, 1989, 1991; Ginsburger-Vogel \& Magniette-Margault, 1981), but there happens to be no such study on $T$. saltator. It is an interesting possibility, but at the present stage, the results are insufficient to answer this question, and further research would be necessary to approach it.

\subsection{Influence of environmental factors}

The population density, expressed both as individuals per $\mathrm{m}^{2}$ and biomass per $\mathrm{m}^{2}$, positively correlated with temperature. Regarding juveniles, a positive correlation was also found with sediment moisture, suggesting that younger individuals are probably more sensitive to dehydration, and concentrate closer to the water line. No other significant correlations were found between population features and environmental factors, but it is often extremely difficult to establish statistically significant links between population dynamics and environmental controls from field data (e.g. Marsden, 1991b).

\subsection{Growth and life cycle}

Based on field data, there is always a relative uncertainty regarding the size of cohorts at the moment of detection due to sampling periodicity. Also, newborn individuals may remain in the brood pouch, where the osmotic environment is under maternal control for variable periods, depending on the external conditions (Morritt \& Spicer, 1999). Despite possible bias, field growth rates were estimated from cohort recognition and tracking. The results show that the population presenting the largest adults, both in terms of weight and body length, was the one from the Atlantic, while the smallest individuals came from Italy, with individuals from the Tunisian population ranging in the middle. Morphological differences between Mediterranean and Atlantic populations of Talitrus saltator have been observed before (Scapini, Campacci, \& Audoglio, 1999), but it was then hypothesized that such differences would not correspond to a geographic cline, depending instead on local ecological features.

The life span estimations, as well as the minimum periods necessary for sexual differentiation and for female's sexual maturation after birth (Table 2), were very different from observations on Talitrus saltator carried out in the British Isles (Cornwall), using approximately the same methodologies. There, life span was estimated at 21 months for males and 18 months for females, while sexual differentiation occurred 3 or 4 months after birth (Williams, 1978). The results are, nevertheless, closer to life-span estimations obtained for other talitrid species: 12 months for Orchestia gammarellus in the British Isles (Jones \& Wigham, 1993), 6-8 months for Orchestia meditterranea, Orchestia montagui, and Orchestia platensis in the Mediterranean (Louis, personal communication), 13 months for Talorchestia quoyana in New Zealand (Marsden, 1991a), or 12-21 months for Pseudorchestoidea brasiliensis in Brazil (Cardoso \& Veloso, 1996). Life span among talitrids appears, therefore, to be extremely variable.

As a whole, the present results, when combined with the ones from Williams (1978) and Scapini, Campacci, et al. (1999), suggest that there might be a geographic cline variation in Talitrus saltator populations, with adult size and life span decreasing from northern European populations towards the Mediterranean ones.

Regarding the life cycle characteristics, it is concluded that the three studied populations of Talitrus saltator produced two generations within the same reproductive period, and apparently females from each cohort breed at least twice. This typically characterizes bivoltin life cycles, involving iteroparous females (Table 2), which contrasts with the univoltin life cycle observed farther to the north, in the British Isles (Williams, 1978). The same plasticity was found in the life cycles from talitrid species-for instance, Orchestia gammarellus may vary from bivoltin, in the Baltic (Persson, 1999) to multivoltin in a sewage treatment works in Britain (Jones \& Wigham, 1993) - and appears to be a common feature among amphipods that may eventually play a role in speciation processes (see Wildish, 1982).

\subsection{Secondary production}

With regard to growth production, higher values found in spring and summer at Lavos and Collelungo (Table 2) are probably related to increased temperature and metabolism, and also, for sure, with more available food sources in the beaches. At Zouara, nevertheless, the extremely low values of both growth and elimination productions found during late spring and summer had certainly to do with the decrease of population density in the beach discussed previously.

Increased elimination production is usually related with higher mortality rates, and this explanation is, to a certain extent, consistent with observations carried out at Lavos and Collelungo. In fact, higher mortalities of older, and therefore larger, individuals are expected to occur after reproductive efforts (spring and summer), and also as a response to more extreme conditions during winter. However, once again, population movements from the beach to the dunes may predictably contribute to an artificial increase of elimination production estimations, which may hide the real picture.

Values of growth and elimination productions estimated here (Table 2 ) could not be directly compared with other results, since no other studies were found in the 
literature presenting production estimations for Talitrus saltator. A few estimations could, nevertheless, be found for other talitrid species: $P=2.9-7.2 \mathrm{~g} \mathrm{~m}^{-2} \mathrm{yr}^{-1}$ for Talorchestia capensis (DW) (Van Senus \& McLachlan, 1986), approximately equivalent to $51.5-127.9 \mathrm{~kJ} \mathrm{~m}^{-2}$ $\mathrm{yr}^{-1}$ (Jørgensen et al., 1991), with a $P / \bar{B}$ ratio of $2.25 \mathrm{yr}^{-1}$, and $P=0.3 \mathrm{~g} \mathrm{~m}^{-2} \mathrm{yr}^{-1}$ AFDW $\left(7.2 \mathrm{~kJ} \mathrm{~m}^{-2} \mathrm{yr}^{-1}\right)$ for Pseudorchestoidea brasiliensis, with a $P / \bar{B}$ ratio of $2.16-$ $2.3 \mathrm{yr}^{-1}$ (Cardoso \& Veloso, 1996).

Production values estimated here are of the same magnitude as found by Cardoso and Veloso (1996) in Brasilian sandy beaches, but are inferior to those estimated by Van Senus and McLachlan (1986) in South Africa. Differences observed do not appear to have any special meaning, and no emergent pattern is recognisable. Plausibly, different beaches simply offer different food resources, which must reflect on talitrids feeding habits and productivity. It is, nevertheless, worthy to note that at all the three sites studied by us, we found for Talitrus saltator that $P / \bar{B}$ and $E / \bar{B}$ ratios were much higher than those found for Talorchestia capensis, and Pseudorchestoidea brasiliensis. It became, therefore, necessary to assess if the estimations are theoretically consistent.

Wildish (1984) in O'Hanlon \& Bolger (1997) proposed a general equation for amphipods, which relates growth production, biomass, and life span (expressed in years), allowing estimate $P / \bar{B}$ ratios from life span as

$\log _{10} P: \bar{B}=0.66-1.10\left(\log _{10}\right.$ life span $)$

Applying this equation to life spans estimated for the three studied populations, the resulting $P / \bar{B}$ ratios are fully consistent with our field estimations. Moreover, for a life span of 18-21 months (Williams, 1978), the resulting $P / \bar{B}$ ratio will be $2.47-2.93$, corresponding to, approximately, half of the annual turnover in the Lavos population, which again suggests a geographical cline.

At a local scale, from the conservation and management viewpoints, information on dominant species production and $P / \bar{B}$ ratios might be very useful to assess short- and long-term consequences of human actions, like, for instance, nourishment or bulldozing to increase primary dunes on beaches affected by coastal erosion (Petersen, Hickerson, \& Grissom Johnson, 2000). As a whole, results from studies on talitrids reinforce the need to reserve the full range of translittoral habitats, as already suggested by Richardson, Swain, and Wong (1997), which will not necessarily be achieved by establishing reserve boundaries on the basis of vegetation associations.

\section{Acknowledgements}

The authors are indebted to all colleagues who assisted in field and laboratory works. A special thanks goes to
Maria Gabriel Fontes for her precious help in preparing the figures. This work was carried out in the scope of the research project 'Bases for the integrated sustainable management of Mediterranean sensitive coastal ecosystems', funded by the European Union (IC18-CT980270) and by the project POCTI/CTA/36553/00 from FCT. The research complies with the current laws in the countries where it was conducted. We wish to thank the direction of the Parco Regionale della Maremma (Ucellina) and the Delegate of Nefza-Zouara for allowing the samplings on the beaches.

\section{References}

Allen, K. R. (1971). Relation between production and biomass. Journal of the Fisheries Research Board of Canada 28, 1573-1581.

Anastácio, P. M., Gonçalves, S. C., Pardal, M. A., Marques, J. C. (2003). A model for amphipod (Talitrus saltator) population dynamics. Proceedings of the workshop beaches, Florence 2001 [Special issue]. Estuarine, Coastal and Shelf Science 58S, 81-89.

Bertalanffy, L. V. (1957). Quantitative laws in metabolism and growth. Quarterly Review in Biology 32, 217-231.

Borgioli, C., Martelli, L., Porri, F., D’Elia, A., Marchetti, G. M., \& Scapini, F. (1999). Orientation in Talitrus saltator (Montagu): trends in intrapopulation variability related to environmental and intrinsic factors. Journal of Experimental Marine Biology and Ecology 238, 29-47.

Bregazzi, P. K., \& Naylor, E. (1972). The locomotor activity rhythm of Talitrus saltator (Montagu) (Crustacea, Amphipoda). Journal of Experimental Marine Biology and Ecology 57, 375-391.

Brown, A. C., \& McLachlan, A. (1990). Ecology of sandy shores (328 pp.).

Cardoso, R. S., \& Veloso, V. G. (1996). Population biology and secondary production of the sandhopper Pseudorchestoidea brasiliensis (Amphipoda: Talitridae) at Prainha beach, Brazil. Marine Ecology Progress Series 142, 111-119.

Cassie, R. M. (1954). Some uses of probability paper in the analysis of size-frequency distributions. Australian Journal of Marine and Freshwater Research 3, 513-522.

Cassie, R. M. (1963). Tests of significance for probability paper analysis. New Zealand Sciences Review 6, 474-482.

Charfi-Cheikhrouha, F., ElGtari, M., \& Bouslama, M. F. (2000). Distribution and reproduction of two sandhoppers, Talitrus saltator and Talorchestia brito from Zouara (Tunisia). Polskie Archiwum Hydrobiologii 43, 621-629.

Colombini, I., Aloia, A., Bouslama, M. F., ElGtari, M., Fallaci, M., Ronconi, L., Scapini, F., \& Chelazzi, L. (2002). Small-scale spatial and seasonal differences in the distribution of beach arthropods on the northern Tunisian coast. Are species evenly distributed along the shore? Marine Biology. (doi 10.1007/s00227-001-0771-8).

De Matthaeis, E., Cobolli, M., Mattocia, M., \& Scapini, F. (1995). Gepographic variation in Talitrus saltator (Crustacea, Amphipoda): biochemical evidence. Bollettino Zoologico 62, 77-84.

Elliot, J. M. (1977). Statistical analysis of samples of benthic invertebrates (2nd ed., pp. 1-160). Freshwater Biology Association Scientific Publications 25.

Fallaci, M., Aloia, A., Audoglio, M., Colombini, I., Scapini, F., \& Chelazzi, L. (1999). Differences in behavioural strategies between two sympatric talitrids (Amphipoda) inhabiting an exposed sandy beach of the French Atlantic Coast. Estuarine, Coastal and Shelf Science 48, 469-482.

Fialkowski, W., Rainbow, P. S., Fialkowski, E., \& Smith, D. B. (2000). Biomonitoring of trace metals along the Baltic coast of Poland 
using the sandhopper Talitrus saltator (Montagu) (Crustacea, Amphipoda). Ophelia 52, 183-192.

Gerard, J. F., Vancassel, M., \& Laffort, B. (1993). Spread of phenotypic plasticity or genetic assimilation: the possible role of genetic constraints. Journal of Theoretical Biology 164, 341-349.

Ginsburger-Vogel, T. (1989). Determinisme des anomalies de sex-ratio à hérédité paternelle chez le crustacé amphipode Orchestia gammarellus Pallas. Invertebrate Reproduction and Development 16, 183-194.

Ginsburger-Vogel, T. (1991). Intersexuality in Orchestia mediterranea Costa, 1853, and Orchestia aestuarensis Wildish, 1987 (Amphipoda): a consequence of hybridisation or parasitic infestation. Journal of Crustacean Biology 11, 530-539.

Ginsburger-Vogel, T., \& Magniette-Mergault, F. (1981). The effects of temperature on sexual differentiation in the temperature sensitive thylogenic-intersexual offspring of Orchestia gammarellus (Pallas) (Amphipoda: Crustacea). International Journal of Invertebrate Reproduction 4, 39-50.

Harding, J. P. (1949). The use of probability paper for the graphical analysis of polymodal frequency distributions. Journal of the Marine Biological Association of United Kingdom 28, 141-153.

den Hartog, C. (1963). The amphipods of the deltaic region of the rivers Rhine, Meuse, and Acheldt in relation to the hydrography of the area. II. The Talitridae. Netherlands Journal of Sea Research 2, 4-67.

Hazlett, B. A. (1988). Behavioural plasticity as an adaptation to a variable environment. In G. Chelazzi, \& M. Vannini (Eds.), Behavioural adaptation to intertidal life (pp. 317-332). New York: Plenum Press.

Hoffmann, A. A., \& Parsons, P. A. (1991). Evolutionary genetics and environmental stress (296 pp.). Oxford: Oxford University Press.

Jones, M. B., \& Wigham, G. D. (1993). Reproductive biology of Orchestia gammarellus (Crustacea: Amphipoda) living in a sewage treatment works. Journal of the Marine Biological Association of United Kingdon 73, 405-416.

Jørgensen, S. E., Nielsen, S. N., \& Jørgensen, L. A. (1991). Handbook of ecological parameters and ecotoxicology (1263 pp.). Amsterdam: Elsevier.

Kevin, J. G., \& Spicer, J. I. (1998). Do upper thermal tolerances differ geographically separated populations of the beachflea Orchestia gammarellus (Crustacea: Amphipoda)? Journal of Experimental Marine Biology and Ecology 229, 265-276.

Marchetti, G. M., \& Scapini, F. (2002). Statistical analysis of environmental affects on orientation. Proceedings of the workshop beaches, Florence 2001 [Special issue]. Estuarine, Coastal and Shelf Science.

Marques, J. C., Martins, I., Teles-Ferreira, C., \& Cruz, S. (1994). Population dynamics, life history, and production of Cyathura carinata (Krøyer) (Isopoda: Anthuridae) in the Mondego estuary, Portugal. Journal of Crustacean Biology 14, 258-272.

Marques, J. C., \& Nogueira, A. (1991). Life cycle, dynamics, and production of Echinogammarus marinus (Leach) (Amphipoda) in the Mondego estuary (Portugal). Oceanologica Acta 11, 213-223.

Marsden, I. D. (1991a). Kelp-sandhopper interactions on a sand beach in New Zealand. II. Population dynamics of Talorchestia quoyana (Milne-Edwards). Journal of Experimental Marine Biology and Ecology 152, 75-90.

Marsden, I. D. (1991b). Kelp-sandhopper interactions on a sand beach in New Zealand. I. Drift composition and distribution. Journal of Experimental Marine Biology and Ecology 152, 61-74.

Marsden, I. D. (1991c). A comparison of water loss and gill areas in two supralittoral amphipods from New Zealand. Hydrobiologia 223, 149-158.

Morritt, D. (1998). Hygrokinetic responses of talitrid amphipods. Journal of Crustacean Biology 18, 25-35.

Morritt, D., \& Spicer, J. I. (1999). Development ecophysiology of the beachflea Orchestia gammarellus (Pallas) (Crustacea: Amphipoda:
Talitridae). III. Physiological competency as a possible explanation for timing of hatching release. Journal of Experimental Marine Biology and Ecology 232, 275-283.

Nogueira, A. (1992). ANAMOD_Extracção dos componentes modais de distribuições de frequências de variáveis biométricas. Trabalho de Sintese (67 pp.). Provas de Aptidão Pegagógica e de Capacidade Científica, Universidade de Coimbra.

O'Hanlon, R. P., \& Bolger, T. (1997). Biomass, growth and secondary production of Arcitalitrus dorrieni (Crustacea: Amphipoda: Talitridae) at two sites in Co. Galway (Ireland). Journal of Zoology (London) 241, 409-428.

Palluault, M. (1954). Notes écologiques sur le Talitrus saltator. Archives Zoology Expérimentale et Générale 91, 105-129.

Pardal, M. A., Marques, J. C., Metelo, I., Lillebø, A. I., \& Flindt, M. R. (2000). Impact of eutrophication on the life cycle, population dynamics and production of Ampithoe valida (Amphipoda) along an estuarine spatial gradient (Mondego estuary, Portugal). Marine Ecology Progress Series 196, 207-219.

Pennings, S. C., Carefoot, T. H., Zimmer, M., Danko, J. P., \& Ziegler, A. (2000). Feeding preferences of supralittoral isopods and amphipods. Canadian Journal of Zoology 78, 1918-1929.

Persson, L. E. (1999). Growth and reproduction in two brackish water populations of Orchestia gammarellus (Amphipoda: Talitridae) in the Baltic. Journal of Crustacean Biology 19, 53-59.

Persson, L. E. (2001). Dispersal of Platorchestia platensis (Kröyer) (Amphipoda: Talitridae) along Swedish coasts: a slow but successful process. Estuarine, Coastal and Shelf Science 52, 201-210.

Petersen, C. H., Hickerson, D. H. M., \& Grissom Johnson, G. (2000). Short term consequences of nourishment and bulldozing on the dominant large invertebrates of a sandy beach. Journal of Coastal Research 16, 368-378.

Rainbow, P. S., Moore, P. G., \& Watson, D. (1989). Talitrid amphipods (Crustacea) as biomonitors for copper and zinc. Estuarine, Coastal and Shelf Science 28, 567-582.

Richardson, A. M. M. (1993). The distribution of coastal group landhoppers (Crustacea: Amphipoda: Talitridae) related to sea spray at Cox Bight, Tasmania. Papers and Proceedings of the Royal Society of Tasmania 127, 53-60.

Richardson, A. M. M., \& Devitt, D. M. (1984). The distribution of four species of terrestrial amphipods (Crustacea: Talitridae) on Mt. Wellington, Tasmania. Australian Zoological 21, 143-156.

Richardson, A. M. M., Swain, R., \& Wong, V. (1997). Translittoral Talitridae (Crustacea: Amphipoda) and the need to reserve transitional habitats: examples from Tasmanian saltmarshes and other coastal sites. Memoirs of the Museum of Victoria 56, 521-529.

Scapini, F. (1997). Variation in scototaxis and orientation adaptation of Talitrus saltator populations subjected to different ecological constraints. Estuarine, Coastal and Shelf Science 44, 139-146.

Scapini, F., Aloia, A., Bouslama, M. F., Chelazzi, L., Colombini, I., ElGtari, M., Fallaci, M., \& Marchetti, G. M. (2002). Multiple regression analysis of the sources of variation in orientation of two sympatric sandhoppers, Talitrus saltator and Talorchestia brito, from an exposed Mediterranean beach. Behavioural Ecology and Sociobiology 51, 403-414.

Scapini, F., Buiatti, M., De Matthaeis, E., \& Mattoccia, M. (1995). Orientation and heterozygosity of sandhopper populations in relation to stability of beach environments. Journal of Evolutionary Biology 8, 43-52.

Scapini, F., Buiatti, M., \& Fallaci, M. (1989). Family and individual orientation behaviour in sandhoppers. Ethology Ecology and Evolution 1, 241-246.

Scapini, F., Campacci, F., \& Audoglio, M. (1999b). Variation among natural populations of Talitrus saltator (Amphipoda): morphometric analysis. Crustaceana 72, 659-672.

Scapini, F., \& Fasinella, D. (1990). Genetic determination and plasticity in the sun orientation of natural populations of Talitrus saltator. Marine Biology 107, 141-145. 
Scapini, F., Lagar, M. C., \& Mezzeti, M. C. (1993). The use of slope and visual information in sandhoppers: innateness and plasticity. Marine Biology 115, 545-553.

Scapini, F., Porri, F., Borgioli, C., \& Martelli, L. (1999a). Solar orientation of adult and laboratory-born juvenile sandhoppers: inter- and intra-population variation. Journal of Experimental Marine Biology and Ecology 238, 107-126.

Scapini, F., \& Quochi, G. (1992). Orientation in sandhoppers from Italian populations: have they magnetic orientation ability? Bollettino Zoologico 59, 437-442.

Tsubokura, T., Goshima, S., \& Nakao, S. (1997). Seasonal horizontal and vertical distribution patterns of the supralittoral amphipod Trinorchestia trinitatis in relation to environmental variables. Journal of Crustacean Biology 17, 674-686.

Van Senus, P. (1988). Reproduction of the sandhopper, Talorchestia capensis (Dana) (Amphipoda, Talitridae). Crustaceana 55, 93-103.

Van Senus, P., \& McLachlan, A. (1986). Growth. Production, and a partial energy budget for the amphipod, Talorchestia capensis (Crustacea: Talitridae) in the Eastern Cape, South Africa.
Pubblicaziones della Stazione Zoologica di Napoli I: Marine Ecology 7, 165-179.

Weeks, J. M. (1992). The use of the terrestrial amphipod Arcitalitrus dorrieni (Crustacea: Amphipoda: Talitridae) as a potential biomonitor of ambient zinc and copper availabilities in leaf-litter. Chemosphere 24, 1505-1522.

Wildish, D. J. (1982). Evolutionary ecology and reproduction in gammaridean Amphipoda. International Journal of Invertebrate Reproduction 5, 1-19.

Williams, J. A. (1978). The annual pattern of reproduction of Talitrus saltator (Crustacea: Amphipoda: Talitridae). Journal of Zoology (London) 184, 231-244.

Williamson, D. I. (1951a). On the mating and breeding of some semiterrestrial amphipods. Report Dove Marine Laboratory 12(ser. 3), 49-61.

Williamson, D. I. (1951b). Studies in the biology of Talitridae (Crustacea: Amphipoda): visual orientation in Talitrus saltator. Journal of the Marine biological Association of United Kingdom 30, 91-99. 